\title{
Potential of Soil Fertility Management to Improve Essential Mineral Nutrient Concentrations in Vegetables in Dodoma and Kilombero, Tanzania
}

\author{
Nyambilila A. Amuri', Lydia Mhoro', Tumaini Mwasyika², Ernest Semu1 \\ ${ }^{1}$ Department of Soil and Geological Sciences, Sokoine University of Agriculture, Morogoro, Tanzania \\ ${ }^{2}$ Water Institute, Dar Es Salaam, Tanzania \\ Email: nyambilila.amuri@gmail.com
}

How to cite this paper: Amuri, N.A., Mhoro, L., Mwasyika, T. and Semu, E. (2017) Potential of Soil Fertility Management to Improve Essential Mineral $\mathrm{Nu}$ trient Concentrations in Vegetables in Dodoma and Kilombero, Tanzania. Journal of Agricultural Chemistry and Environment, 6, 105-132.

https://doi.org/10.4236/jacen.2017.62007

Received: February 6, 2017

Accepted: May 12, 2017

Published: May 15, 2017

Copyright () 2017 by authors and Scientific Research Publishing Inc. This work is licensed under the Creative Commons Attribution International License (CC BY 4.0).

http://creativecommons.org/licenses/by/4.0/

\begin{abstract}
Collective efforts to fight mineral nutrient malnutrition in humans require consideration of soil fertility management practices (SFMP) in vegetable production. This study aimed at establishing the relationship between SFMP and vegetable nutrient concentration for human health in farming systems of Tanzania. Soil and vegetable samples collected from vegetable growing areas in Kilombero and Dodoma were analyzed for chemical properties and mineral nutrient concentration. Descriptive statistics, analysis of variance and correlation analysis were employed. The results showed that soil $\mathrm{pH}$ in Kilombero ranged from 6.04 to 6.8 and in Dodoma ranged from 6.23 to 8.58. The organic $\mathrm{C}$ was low, ranged from $0.10 \%$ to $1.87 \%$. All soils studied had sufficient $\mathrm{Zn}$ ( 0.45 to $29.3 \mathrm{mg} / \mathrm{kg}), \mathrm{Cu}(0.71$ to $3.23 \mathrm{mg} / \mathrm{kg}$ ), $\mathrm{Fe}$ ( 3.70 to $171.7 \mathrm{mg} / \mathrm{kg}$ ) and $\mathrm{Mn}(2.84$ to $41.38 \mathrm{mg} / \mathrm{kg})$. Zinc concentration in all vegetables ranged from 12.57 to $134.54 \mathrm{mg} / \mathrm{kg}, 14 \%$ of vegetables had low $\mathrm{Zn}(<20 \mathrm{mg} / \mathrm{kg})$ for human health. The $\mathrm{Cu}$ concentration in vegetables ranged from 0.07 to $52.37 \mathrm{mg} / \mathrm{kg}$, and vegetables from Kilombero had very low $\mathrm{Cu}(<0.10 \mathrm{mg} / \mathrm{kg})$ for plant and human nutrition. Vegetable $\mathrm{Fe}$ and $\mathrm{Mn}$ concentration ranged from 152.95 to $1780 \mathrm{mg} / \mathrm{kg}$ and 35.10 to $321.82 \mathrm{mg} / \mathrm{kg}$, respectively. The SFMP used did not affect mineral micronutrients concentration in vegetables, but affected soil $\mathrm{Zn}$, $\mathrm{Cu}, \mathrm{Fe}$ and $\mathrm{Mn}$ concentrations. Soil $\mathrm{pH}, \mathrm{Zn}$, and $\mathrm{CEC}$ correlated with vegetable $\mathrm{Cu}, \mathrm{K}, \mathrm{Mg}, \mathrm{Zn}, \mathrm{P}$ and Fe concentrations, and differed among soils. Therefore, soil properties differed with SFMP, and both determined mineral concentrations in vegetables for human health.
\end{abstract}

\section{Keywords}

Soil Fertility, Nutrient Concentration, Human Mineral Nutrition, Vegetables, 
Dodoma, Kilombero

\section{Introduction}

Mineral micronutrient malnutrition in humans is the major cause of hidden hunger, affecting about $50 \%$ of the world population [1] [2]. The micronutrient malnutrition is severe in developing and middle income countries, where it is estimated that $1.5 \%$ to $12 \%$ of one out of 10 years' disabilities that occur at national scale is due to micronutrients deficiency in diets [3]. A micronutrient nutrition survey in Tanzania showed that $35 \%$ of children under five years of age are iron deficient while $59 \%$ are anemic, and 30\% of women aged 15 to 49 are iron deficient while $41 \%$ are having anemia [4]. In the 2010 nutritional survey $\mathrm{Zn}$ status was not determined, but world statistics showed that $20 \%$ of the world populations are at risk of $\mathrm{Zn}$ deficiency according to [5], and that $\mathrm{Zn}$ status is strongly associated with that of $\mathrm{Fe}$ [6]. The magnitude of hidden hunger is severe in Tanzania, with $2.5 \%$ of the population disability adjusted life years (DALY) due to micronutrients deficiencies [3]. Other reports also showed that $\mathrm{Fe}$ and $\mathrm{Zn}$ are problems in Tanzanian communities, especially for children under 5 years and for pregnant women [7] [8]. The major cause of micronutrient mineral malnutrition is intake of poor quality diets consisting of staples with low mineral micronutrient contents and low proportions of vegetables, fruits and meat in the diets [9]. Deficiencies of micronutrients in diets of infants and toddlers exist in developing countries [10]. It is therefore evident that micronutrient mineral malnutrition is widespread among communities and is largely due to low-nutrient diets.

In Tanzania, all cereal-, roots- and tubers-based stable foods are usually eaten along with vegetables in most average and low income families. These diets are dominated by staple crops such as maize, sorghum, millet, cassava, rice, sweet potatoes and green banana. Most of these staples are of inherently low concentration of mineral nutrients, but relatively inexpensive [11]. Vegetables are an important component of daily diets of many people and an important source of minerals, vitamins, and antioxidants essential for human health. Thus, addressing hidden hunger mineral nutrition requires inclusion of vegetables as a major dietary component of meals of common Tanzanians.

Prevalence of hidden hunger micronutrient deficiencies in developing countries, including Tanzania, is partly attributed to the lack of a comprehensive and multi-sector approach to address micronutrient malnutrition that includes agriculture [3]. Most of the efforts to curb mineral malnutrition have been through nutrition programs such as food distribution, supplementary feeding and food fortification [12] [13]. Thus, integration of agronomic practices to address the increasing hidden hunger problems is required to reverse the trend of mineral malnutrition. Efforts to fight hunger and hidden hunger through agricultural production systems require consideration of improving vegetable mineral pro- 
files. One aspect of vegetable quality is its essential micronutrient element contents in sufficient levels that will neither cause malnutrition nor negative effect on human health.

Human beings require essential mineral micronutrients such as $\mathrm{Cu}, \mathrm{Zn}, \mathrm{Fe}$ and Mn for physiological processes and insure good health [14]. All these micronutrient elements are also essential mineral elements for plant growth, and the primary source of all these mineral micronutrients is the soil where plants are grown. Plants absorb and accumulate mineral micronutrients in harvestable plant parts that are eaten by humans. In both humans and plants, excessive concentrations of micronutrients are toxic, and may cause human health problems and reduction of plant growth and yields. Some extensive studies showed that soil properties influence mineral contents in food crops grown in different soils [15]. Other studies reported higher food crop micronutrient element concentrations than the allowable levels for human health when the crops were grown in contaminated sites [16] [17] [18]. Information on the mineral micronutrient profiles of some common vegetables in Tanzania in relation to soils and management practices is scant, and needs to be established. Such information will be of help in efforts to complement food fortification programmes targeting micronutrient mineral elements which may be deficient in both soils and vegetables. Also, while increasing mineral micronutrient nutrition is essential for human health, ensuring sustained adequate levels of these micronutrients is more important.

The objective of this study was to assess the potential contribution of soil fertility management on vegetable mineral nutrient quality under small scale vegetable farming systems of humid and semi-arid areas of Tanzania for improved human health. Specifically, i) to determine the physical-chemical properties of vegetable growing soils under different management practices in humid and semi-arid areas, ii) to establish the mineral micronutrient profiles of common vegetables grown in Kilombero and Dodoma municipality and deduce whether they are sufficient, deficient or toxic for both plant and human health, and iii) to determine the relationship between soil fertility management and mineral nutrient concentration of vegetables.

\section{Materials and Methods}

\subsection{Description of the Study Areas}

This study was conducted in Kilombero district and Dodoma Municipality, Tanzania. Kilombero district is located in eastern Tanzania between Longitude $8^{\circ} 15^{\prime} 00^{\prime \prime} \mathrm{E}$ and Latitude $36^{\circ} 25^{\prime} 00^{\prime \prime} \mathrm{S}$, while Dodoma Municipality is located in central Tanzania between Longitude $36^{\circ} 00^{\prime} 00^{\prime \prime} \mathrm{E}$ and Latitude $6^{\circ} 00^{\prime} 00^{\prime \prime} \mathrm{S}$. The two areas have contrasting climate; Kilombero district has warm and humid tropical climate with annual minimum and maximum temperature of $26^{\circ} \mathrm{C}$ and $32^{\circ} \mathrm{C}$, respectively. The annual mean rainfall of Kilombero ranges from $1200 \mathrm{~mm}$ to $1400 \mathrm{~mm}$. The dominant soils of Kilombero are alluvial and Mang'ula area, where the studies were undertaken, is gleyic Cambisol (loamy) soil type [19] de- 
veloped from sediments from the Kilombero River and Udzungwa Mountains. On the other hand, Dodoma Municipality climate is semi-arid, with average annual temperature range of $22^{\circ} \mathrm{C}$ and mean annual rainfall of $500 \mathrm{~mm}$ [20]. The soils of Dodoma vary from reddish-brown clay and loamy in the foot slopes of metamorphic and granitic hills to brownish loamy and sandy colluvium in the well-drained upland plains while the dark, sticky, cracking and friable clays dominate the poorly drained areas of the lowlands [21]. The red soils of Hombolo area fall under haplic cutanic Acrisols while sandy soils of Ihumwa area fall under the haplic Cambisol soil type [22].

\subsection{Soil and Vegetable Sampling}

Soil and vegetable samples were collected from Mang'ula and Mgudeni sites in Kilombero district (Table 1, Figure 1), while in Dodoma samples were collected from Hombolo (Table 2, Figure 2) and Ihumwa (Table 3, Figure 3) sites. These sites are among the major vegetable growing areas in the Kilombero district and Dodoma Municipality. In each site, several farms were selected randomly. Information on soil fertility and water management were recorded for each farm as shown in Tables 1-3. Vegetable samples were collected by cutting the vegetables using a clean knife in the same way the vegetables are normally harvested. Three vegetable samples of the same type (species) and in similar management practices were collected per farm, making three replications. The vegetable samples were collected at the growth stage required for vegetable harvesting. The vegetable samples collected were placed in a clean paper bags. The composite soil samples were collected at $20 \mathrm{~cm}$ depth using an auger in close proximity to the spot where vegetable samples were collected. The composite soil sample was obtained by mixing about eight subsamples. The soil samples were also collected in three replications as were the vegetable samples. The geographical coordinates of each site studied were recorded using a Garmin Global Position System (GPS) model eTrexHC series 2007, KS, USA, and are presented in Tables 1-3. The vegetable and soil samples were transported to the Soil and Plant Analysis Laboratory, Sokoine University of Agriculture (SUA), Morogoro, Tanzania, for chemical analysis.

Table 1. Description of sites and vegetable samples collected from two sites in Kilombero, Tanzania.

\begin{tabular}{|c|c|c|c|c|c|}
\hline Site & $\begin{array}{l}\text { Farm \& Soil } \\
\text { sample ID }\end{array}$ & Vegetable sample collected & Eastings & Northings & Fertility and soil-water management \\
\hline \multirow[t]{3}{*}{ Mgudeni } & Mgudeni 1 & Chinese cabbage (Brassica chinensis L.) & $07^{\circ} 50^{\prime} 08.7^{\prime \prime} \mathrm{E}$ & $036^{\circ} 53^{\prime} 15.6^{\prime \prime S}$ & FYM, irrigated with stream water \\
\hline & Mgudeni 2 & Sweet potato leaves (Ipomea batatas L.) & -do- & -do- & FYM, irrigated with stream water \\
\hline & Mgudeni 3 & Amaranths (Amaranthus hybridus L.) & -do- & -do- & $\begin{array}{l}\text { Compost }+ \text { rice husks, irrigated with stream } \\
\text { water }\end{array}$ \\
\hline \multirow[t]{2}{*}{ Mang'ula } & Mang'ula 1 & Kale (Brassica oleracea L.) & $07^{\circ} 05^{\prime} 08.8^{\prime \prime} \mathrm{E}$ & $036^{\circ} 53^{\prime} 15.6^{\prime \prime S}$ & FYM + Urea, irrigated with stream water \\
\hline & Mang'ula 2 & Amaranths (Amaranthus hybridus L.) & -do- & - do- & FYM + Urea, irrigated with stream water \\
\hline Site & $\begin{array}{l}\text { Farm \& Soil } \\
\text { sample ID }\end{array}$ & Vegetable sample collected & Eastings & Northings & Fertility and soil-water management \\
\hline
\end{tabular}

FYM = Farm Yard Manure; ID = identification . 


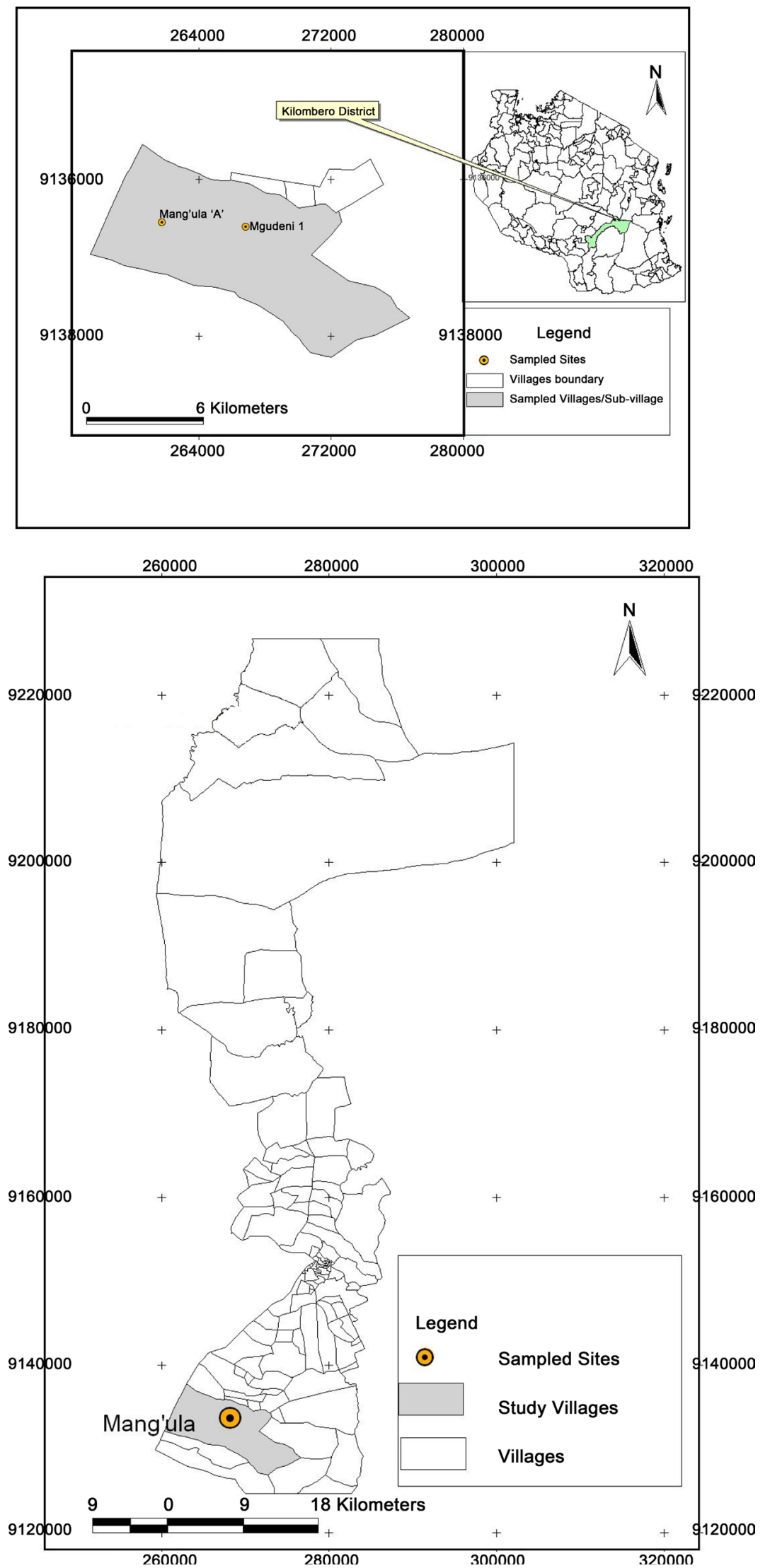

Figure 1. Geographical location of villages and sites where soil and vegetable samples were collected in Kilombero District, Tanzania. 
Table 2. Description of sites and vegetable samples collected from two sites in Hombolo, Dodoma Municipal, Tanzania.

\begin{tabular}{|c|c|c|c|c|c|}
\hline Site & $\begin{array}{l}\text { Farm \& Soil } \\
\text { sample ID }\end{array}$ & Vegetable sample collected & Eastings & Northings & Fertility and soil-water management \\
\hline \multirow[t]{3}{*}{ Bwawani } & Bwawani 1 & Sweet potato leaves (Ipomea batatas L.) & $05^{\circ} 56^{\prime} 57.9^{\prime \prime} \mathrm{E}$ & $035^{\circ} 58^{\prime} 16.6^{\prime \prime S}$ & FYM, irrigated with HIS irrigation canal water \\
\hline & Bwawani 2 & Chinese cabbage (Brassica chinensis L.) & - do- & -do- & FYM, irrigated with HIS irrigation canal water \\
\hline & Bwawani 5 & $\begin{array}{l}\text { Swiss chard (Beta vulgaris subsp vulga- } \\
\text { ris) }\end{array}$ & - do- & - do- & FYM, irrigated with HIS irrigation canal water \\
\hline \multirow[t]{2}{*}{ Bwawani 3} & Bwawani 3 & Kale (Brassica oleracea L.) & $05^{\circ} 57^{\prime} 01.9^{\prime \prime} \mathrm{E}$ & $035^{\circ} 58^{\prime} 18.7^{\prime \prime} \mathrm{S}$ & $\begin{array}{l}\text { FYM + Urea, irrigated with HIS irrigation canal } \\
\text { water }\end{array}$ \\
\hline & Bwawani 4 & Chinese cabbage (Brassica chinensis L.) & - do- & - do- & $\begin{array}{l}\text { FYM + Urea, irrigated with HIS irrigation canal } \\
\text { water }\end{array}$ \\
\hline Zepisa & Zepisa & Amaranths (Amaranthus hybridus L.) & $05^{\circ} 56^{\prime} 27.8^{\prime \prime} \mathrm{E}$ & $035^{\circ} 55^{\prime} 17.0^{\prime \prime} \mathrm{S}$ & FYM, irrigated with bore hole well water \\
\hline Bwawani & Bwawani 1 & Sweet potato leaves (Ipomea batatas L.) & $05^{\circ} 56^{\prime} 57.9^{\prime \prime} \mathrm{E}$ & $035^{\circ} 58^{\prime} 16.6^{\prime \prime S}$ & FYM, irrigated with HIS irrigation canal water \\
\hline
\end{tabular}

FYM = Farm Yard Manure; HIS - Hombolo Irrigation scheme; ID = identification.

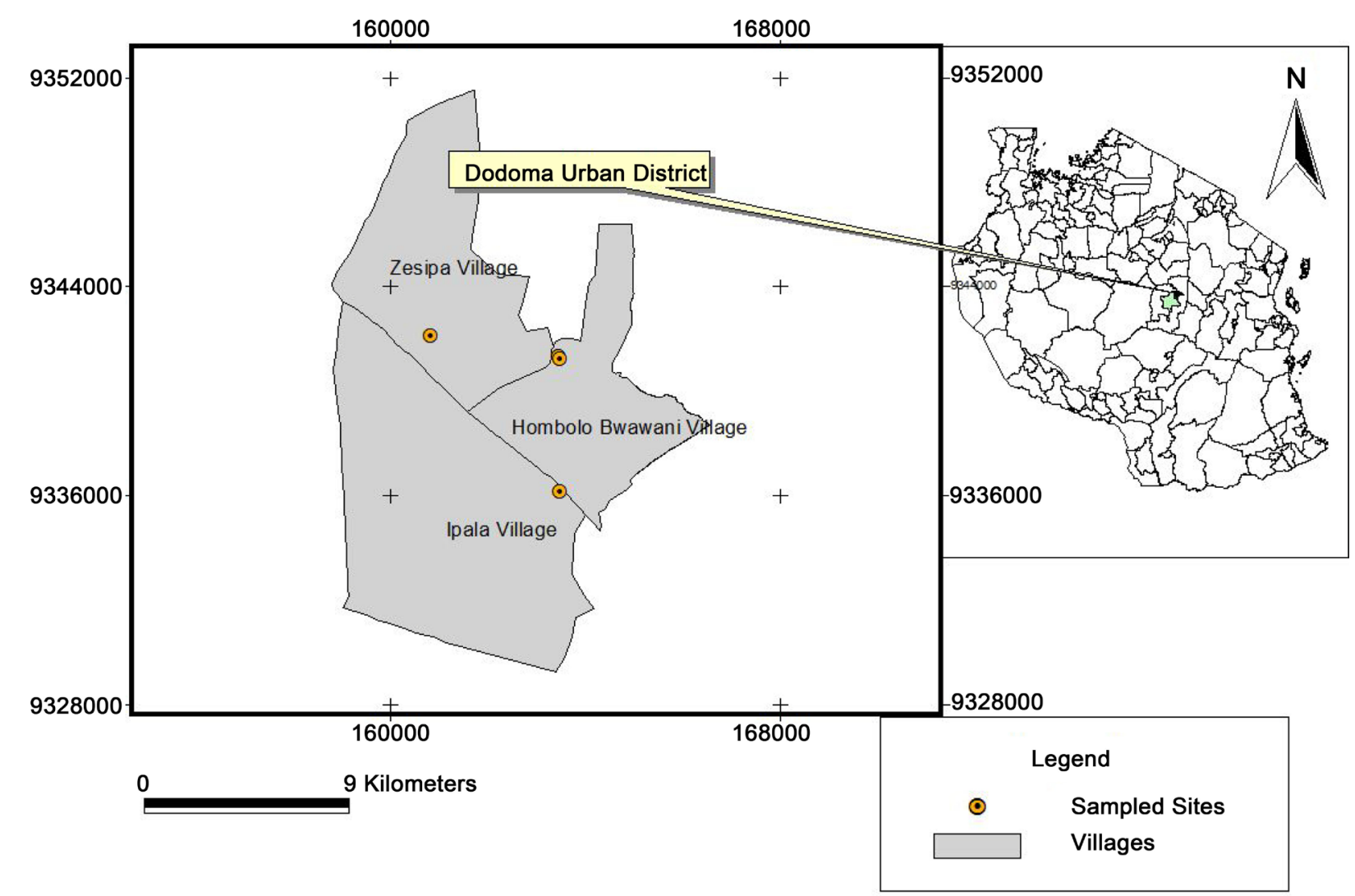

Figure 2. Geographical location of Hombolo, Bwawani, Ipala and Zepisa villages and respective sites where soil and vegetable samples were collected in Dodoma Municipality, Tanzania.

\subsection{Soil and Vegetables Samples Preparations}

Each soil and vegetables sample was air dried in a dust free screen house. The air-dried soil samples were ground to pass through a 2-mm sieve for physical and chemical analysis. The air-dried vegetable samples were subsequently oven dried at $70^{\circ} \mathrm{C}$ to constant weight. The oven-dried vegetable samples were then ground to fine powder using a plant grinder, and stored in clean plastic bags (zip 
Table 3. Description of sites and vegetable samples collected from two sites in Ihumwa, Dodoma Municipal, Tanzania.

\begin{tabular}{|c|c|c|c|c|c|}
\hline Site & $\begin{array}{l}\text { Farm \& Soil } \\
\text { sample ID }\end{array}$ & Vegetable sample collected & Eastings & Northings & Fertility and soil-water management \\
\hline \multirow[t]{4}{*}{ Chididimo 1} & Chididimo 1 & Kale (Brassica oleracea L.) & $06^{\circ} 09^{\prime} 16.7^{\prime \prime} \mathrm{E}$ & $035^{\circ} 54^{\prime} 03.8^{\prime \prime} \mathrm{S}$ & FYM, irrigated with bore hole well water \\
\hline & Chididimo 2 & Mnavu (Solanum nigram L.) & - do- & - do- & Urea, irrigated with bore hole well water \\
\hline & Chididimo 3 & Amaranths (Amaranthus hybridus L.) & -do- & -do- & Urea, irrigated with bore hole well water \\
\hline & Chididimo 4 & $\begin{array}{c}\text { Swiss chard (Beta vulgaris subsp vulga- } \\
\text { ris) }\end{array}$ & - do- & - do- & FYM + Urea, irrigated with bore hole well water \\
\hline Chididimo 5 & Chididimo 5 & Chinese cabbage (Brassica chinensis L.) & $06^{\circ} 09^{\prime} 14.6^{\prime \prime} \mathrm{E}$ & $035^{\circ} 54^{\prime} 05.0^{\prime \prime} \mathrm{S}$ & FYM + Urea, irrigated with bore hole well water \\
\hline \multirow[t]{3}{*}{ Shuleni 1} & Shuleni 1 & Amaranths (Amaranthus hybridus L.) & $06^{\circ} 10^{\prime} 07.5^{\prime \prime} \mathrm{E}$ & $035^{\circ} 52^{\prime} 51.3^{\prime \prime} \mathrm{E}$ & FYM, irrigated with bore hole well water \\
\hline & Shuleni 2 & Sweet potato leaves (Ipomea batatas L.) & -do- & - do- & FYM + Urea, irrigated with bore hole well water \\
\hline & Shuleni 4 & Chinese cabbage (Brassica chinensis L.) & -do- & -do- & FYM + Urea, irrigated with bore hole well water \\
\hline Shuleni 3 & Shuleni 3 & Sweet potato leaves (Ipomea batatas L.) & $06^{\circ} 10^{\prime} 17.9^{\prime \prime} \mathrm{E}$ & $035^{\circ} 52^{\prime} 45.2^{\prime \prime} \mathrm{S}$ & FYM, irrigated with bore hole well water \\
\hline Shuleni 5 & Shuleni 5 & Kale (Brassica oleracea L.) & $06^{\circ} 09^{\prime} 16.7^{\prime \prime} \mathrm{E}$ & $035^{\circ} 54^{\prime} 03.8^{\prime \prime} \mathrm{S}$ & Urea + CAN with bore hole well water \\
\hline
\end{tabular}

FYM = Farm Yard Manure; HIS - Hombolo Irrigation scheme; ID = identification.

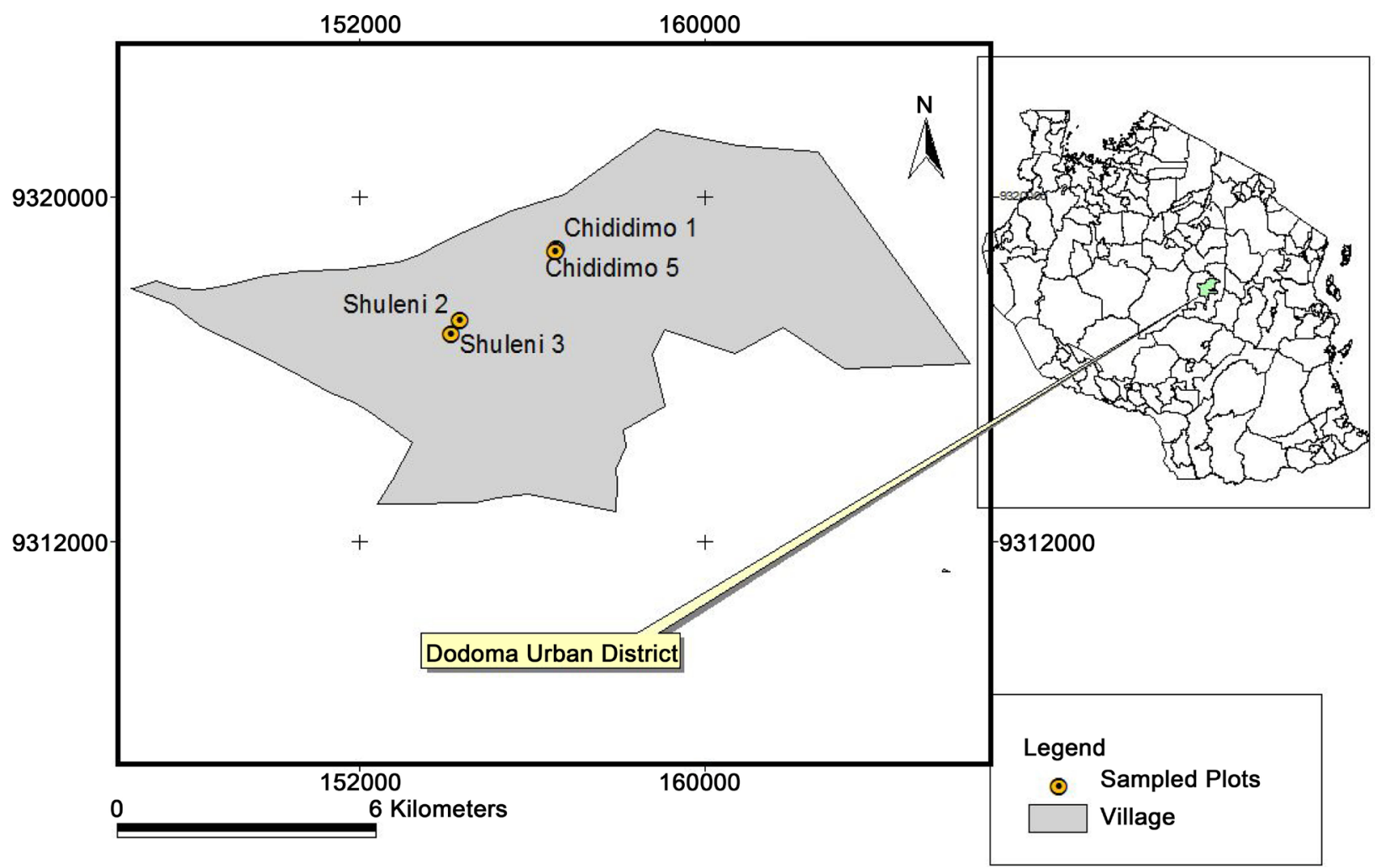

Figure 3. Geographical location of Ihumwa village and sites where soil and vegetable samples were collected in Dodoma Municipal, Tanzania.

lock bags) at room temperature of about $25^{\circ} \mathrm{C}$ for chemical analysis.

\subsection{Soil Analysis}

The soil samples were analyzed for $\mathrm{pH}$, electrical conductivity (EC), organic $\mathrm{C}$, total $\mathrm{N}$, available $\mathrm{P}$, exchangeable $\mathrm{K}$ and the micronutrients $\mathrm{Cu}, \mathrm{Fe}, \mathrm{Zn}$ and $\mathrm{Mn}$. 
Soil $\mathrm{pH}$ and EC was determined in 1:2.5 soil:water ratio by electrode method using $\mathrm{pH}$ meter and EC meter, respectively [23]. Organic $\mathrm{C}$ was determined by the Walkey-Black wet oxidation method [24]. Total $\mathrm{N}$ was determined by micro-Kjeldahl wet digestion-distillation method and quantified by titration with standard acid [25]. Available $\mathrm{P}$ was determined using the Bray 1 method by extracting $\mathrm{P}$ with dilute $\mathrm{NH}_{4} \mathrm{~F}-\mathrm{HCl}$ for soil with $\mathrm{pH}<7$ [26]. Available $\mathrm{P}$ was extracted by $\mathrm{NaHCO}_{3}$ solution for soils with $\mathrm{pH}>7$ as per [27]. Available $\mathrm{P}$ was quantified by UV/Vis spectrophotometer at $884 \mathrm{~nm}$ after color development by the Molybdenum blue method described by [28]. Micronutrients $(\mathrm{Cu}, \mathrm{Fe}, \mathrm{Mn}$ and $\mathrm{Zn}$ ) were extracted by Diethylenetriaminepentaacetic acid (DTPA) in a mixture of $0.01 \mathrm{M} \mathrm{CaCl}_{2}$ and $0.1 \mathrm{M}$ Triethanolamine (TEA) buffered at $\mathrm{pH} 7.3$ [29] and quantified by Atomic Absorption Spectrophotometer (AAS).

\subsection{Vegetable Sample Analysis for $\mathrm{Zn} \mathrm{Cu} \mathrm{Fe} \mathrm{and} \mathrm{Mn}$}

One gram of ground vegetable samples were weighed in crucibles and digested by the dry ash method by heating the samples at $600^{\circ} \mathrm{C}$ in a muffle furnace for 2 hrs. The ashed samples were extracted with $10 \mathrm{ml}$ of $6 \mathrm{~N} \mathrm{HCl}$ and made to $50 \mathrm{ml}$ with distilled water in a volumetric flask [30]. The concentrations of $\mathrm{Cu}, \mathrm{Fe}, \mathrm{Mn}$ and $\mathrm{Zn}$ in the extract were determined by Atomic absorption spectrophotometer (UNICAM 919) at $324.8 \mathrm{~nm}, 248.3 \mathrm{~nm}, 279.5 \mathrm{~nm}$ and $\mathrm{Zn} 213.9 \mathrm{~nm}$, respectively. Standard reference (in-house) soil and plant samples were used for quality control and the recovery of $>90 \%$ in all analyzed elements was obtained, which is acceptable for accuracy and precision of analytical results.

\subsection{Statistical Analysis}

Descriptive statistics were used to determine the levels of mineral elements in soils and vegetables. Correlation analysis was also employed to determine relationships between the soil and vegetable mineral contents across all fertility management practices. The influence of soil properties $(\mathrm{pH}, \mathrm{OC}$, macro- and micro-nutrient concentrations) on the availability/uptake of nutrients in the vegetables was determined by simple correlation analysis. Analysis of variance using mixed model was used to determine effects of soil fertility management practices on soil properties and vegetable nutrient concentrations in each site, separately. Farms were considered random while SFMP was considered a fixed effect. All statistical analyses were carried out using SAS software version 9.00 [31].

\section{Results and Discussion}

\subsection{Soil Chemical Properties of Vegetable Garden Farms in Kilombero and Dodoma}

Soil chemical properties and nutrient contents in soils are essential in determining the nutrient availability to plants. The soil $\mathrm{pH}$ of vegetable growing soils of Kilombero ranged from 6.04 to 6.85 while soil $\mathrm{pH}$ in Hombolo ranged from 7.24 to 8.58 and that of Ihumwa ranged from 6.23 to 8.53 (Table 4). The organic $\mathrm{C}$ is all gardens in all sites ranged from $0.10 \%$ to $1.87 \%$ (Table 4 ), categorized as very 
Table 4. Soil fertility status of the vegetable garden soils of the vegetable-growing sites of Kilombero district and Dodoma Municipality, Tanzania.

\begin{tabular}{|c|c|c|c|c|c|c|c|c|c|c|}
\hline \multirow{2}{*}{ Site } & \multirow{2}{*}{ Garden } & \multirow{2}{*}{$\begin{array}{l}\text { Soil pH } \\
\left(\mathrm{H}_{2} \mathrm{O}\right)\end{array}$} & \multirow{2}{*}{$\begin{array}{c}\mathrm{EC} \\
\mathrm{dS} / \mathrm{m}\end{array}$} & \multirow{2}{*}{$\begin{array}{l}\text { OC } \\
(\%)\end{array}$} & \multirow{2}{*}{$\begin{array}{l}\text { Avail. P } \\
\text { mg/kg }\end{array}$} & \multirow{2}{*}{$\begin{array}{c}\text { Exch K } \\
\text { cmolc/kg }\end{array}$} & $\mathrm{Zn}$ & $\mathrm{Cu}$ & $\mathrm{Fe}$ & $\mathrm{Mn}$ \\
\hline & & & & & & & \multicolumn{4}{|c|}{$\mathrm{mg} / \mathrm{kg}$} \\
\hline \multirow[t]{5}{*}{ Kilombero } & Mgudeni 1 & 6.85 & 0.01 & 0.20 & 78.80 & 0.72 & 11.20 & 2.73 & 62.70 & 20.3 \\
\hline & Mgudeni 2 & 6.09 & 0.13 & 0.33 & 131.47 & 0.60 & 19.27 & 2.90 & 171.70 & 41.4 \\
\hline & Mgudeni 3 & 6.04 & 0.17 & 0.30 & 133.83 & 0.66 & 29.30 & 3.23 & 116.48 & 28.2 \\
\hline & Mang'ula 1 & 6.45 & 0.15 & 0.17 & 61.97 & 0.38 & 4.63 & 2.53 & 58.27 & 38.8 \\
\hline & Mangula 2 & 6.72 & 0.06 & 0.20 & 52.90 & 0.78 & 4.23 & 2.07 & 44.3 & 28.6 \\
\hline \multirow[t]{7}{*}{ Hombolo } & Bwawani 1 & 8.04 & 0.29 & 0.63 & 3.79 & 0.72 & 2.31 & 1.07 & 9.42 & 18.8 \\
\hline & Bwawani 2 & 8.47 & 0.20 & 0.89 & 5.57 & 1.89 & 0.47 & 1.37 & 3.70 & 11.7 \\
\hline & Bwawani 3 & 8.58 & 0.35 & 1.34 & 22.07 & 0.98 & 4.36 & 1.19 & 11.05 & 13.5 \\
\hline & Bwawani 4 & 8.34 & 0.35 & 1.22 & 9.86 & 1.00 & 3.59 & 1.10 & 11.15 & 16.0 \\
\hline & Bwawani 5 & 8.31 & 0.29 & 0.92 & 21.71 & 2.26 & 1.79 & 1.10 & 4.98 & 11.0 \\
\hline & Zepisa & 7.24 & 0.18 & 1.28 & 17.90 & 1.37 & 3.76 & 1.15 & 19.53 & 9.86 \\
\hline & Ipala & 7.33 & 0.04 & 0.96 & 22.88 & 1.52 & 2.31 & 1.75 & 22.18 & 12.2 \\
\hline \multirow[t]{10}{*}{ Ihumwa } & Chididimo 1 & 8.53 & 0.23 & 1.35 & 12.15 & 0.07 & 1.21 & 1.43 & 6.25 & 6.7 \\
\hline & Chididimo 2 & 7.97 & 0.20 & 1.03 & 3.78 & 0.12 & 1.34 & 1.14 & 5.84 & 6.9 \\
\hline & Chididimo 3 & 8.10 & 0.32 & 0.74 & 9.60 & 0.11 & 1.49 & 1.14 & 5.13 & 7.7 \\
\hline & Chididimo 4 & 7.93 & 0.31 & 1.87 & 27.58 & 0.19 & 3.16 & 1.02 & 7.38 & 10.0 \\
\hline & Chididimo 5 & 8.17 & 0.17 & 1.09 & 17.31 & 0.37 & 2.84 & 0.78 & 4.72 & 9.0 \\
\hline & Shuleni 1 & 7.17 & 0.46 & 0.64 & 8.87 & 0.21 & 1.63 & 1.12 & 7.17 & 11.2 \\
\hline & Shuleni 2 & 6.84 & 0.18 & 1.17 & 17.89 & 0.35 & 2.86 & 0.90 & 7.88 & 10.7 \\
\hline & Shuleni 3 & 7.43 & 0.15 & 0.95 & 7.57 & 0.37 & 2.66 & 0.75 & 6.76 & 10.9 \\
\hline & Shuleni 4 & 7.60 & 0.08 & 0.06 & 3.36 & 0.33 & 0.45 & 0.71 & 3.70 & 6.0 \\
\hline & Shuleni 5 & 6.23 & 0.15 & 0.10 & 15.48 & 0.33 & 1.30 & 0.75 & 10.85 & 2.8 \\
\hline
\end{tabular}

${ }^{*} \mathrm{EC}=$ electrical conductivity; $\mathrm{OC}=$ Organic carbon; Avail. $\mathrm{P}=$ available phosphorus; $\mathrm{Zn}=$ extractable zinc; $\mathrm{Cu}=$ extractable copper; $\mathrm{Fe}=$ extractable iron; $\mathrm{Mn}=$ extractable manganese.

low organic C $(<2.0 \%)$ according to [32]. All gardens' soils in Kilombero had adequate levels of available P ranging from 52.90 to $133.83 \mathrm{mg} \mathrm{P} / \mathrm{kg}$ (Table 4). The available $\mathrm{P}$ in soils in Hombolo and Ihumwa ranged from 3.79 to $27.58 \mathrm{mg}$ $\mathrm{P} / \mathrm{kg}$ (Table 4 ), of which about $47 \%$ were of low available $\mathrm{P}$ of $<15 \mathrm{mg} / \mathrm{kg}$ suggested by [32]. All vegetable-growing soils had adequate available $\mathrm{K}$ of $>0.20$ according to [32], except three soils in Chididimo vegetable farms in Ihumwa, which were deficient in exchangeable $\mathrm{K}$.

Soil $\mathrm{pH}$ and SOM are the major determinants of micronutrient availability in plants, and could contribute to micronutrient elements contents in vegetables. The soil $\mathrm{pH}$ range of the vegetable garden farms in Kilombero is adequate for good growth and yields of most vegetable. This is because the $\mathrm{pH}$ range of 6.5 to 6.8 does not pose limitations to availability of nutrients in terms of solubility of nutrients and will not cause plant root injury [33]. On the other hand, the soil 
$\mathrm{pH}$ in most of the vegetable farms in Dodoma are on the higher side (>pH 7.0), which may limit availability of $\mathrm{P}, \mathrm{Zn}$, and may favor excessive loss of $\mathrm{N}$ in the ammonium form through hydrolysis of $\mathrm{NH}_{4}^{+}$to $\mathrm{NH}_{3}$ gas [34] [35]. The low soil organic $\mathrm{C}$ in all vegetable farms in the study area showed that the management practices used in vegetable production do not promote increase in soil organic matter. In all vegetable-growing areas farm yard manure and other organic amendments were reported to be used. These results suggests that the quantity applied is either insufficient to build up and maintain soil organic matter for sustainable vegetable production or the rate of SOM turnover is high. Gardens in Kilombero have relatively lower soil organic $\mathrm{C}$ of $<1$ than soils of Dodoma. This is because the use of manure in vegetable production is lower in Kilombero than in Dodoma [36].

High available $\mathrm{P}$ in the soils of Kilombero vegetable gardens is due to use of DAP fertilizer [36] while in Dodoma most of the $\mathrm{P}$ is supplied from manure, a poor source of $\mathrm{P}$. The results further confirm that $\mathrm{P}$ from manure is low, and that is why $47 \%$ of the gardens in Dodoma sites had low P despite receiving manure as source of nutrients. The high soil $\mathrm{pH}$ in Dodoma soils will further reduce $\mathrm{P}$ availability to vegetable plants and affect vegetable growth and yield. The $\mathrm{pH}>7$ in these gardens from Dodoma shows there is a need to use higher rates of FYM than the current rates, which are generally below the 7 to $12 \mathrm{t} / \mathrm{ha}$ reported to increase yields of leafy vegetables [37]. Adequate $\mathrm{K}$ in all sites suggests that the use of organic amendments such as rice husks in Kilombero and manure in Dodoma supplied adequate amounts of K. However, increased use of organic fertilizers or of $\mathrm{K}$ containing fertilizers should be sustained to enhance $\mathrm{K}$ availability.

\subsection{Micronutrient Levels in Vegetable-Growing Soils}

Adequate levels of essential micronutrients in soils are the primary source of micronutrients in vegetables and for human health. The $\mathrm{Zn}$ content in all vegetable-growing soils studied ranged from 0.45 to $29.3 \mathrm{mg} / \mathrm{kg}$, Cu ranged from 0.71 to $3.23 \mathrm{mg} / \mathrm{kg}$, Fe ranged from 3.70 to $171.7 \mathrm{mg} / \mathrm{kg}$, while $\mathrm{Mn}$ ranged from 2.84 to $41.38 \mathrm{mg} / \mathrm{kg}$ (Table 5). All these micronutrient concentrations are below the toxic levels in soils of $170 \mathrm{mg} / \mathrm{kg}$ for $\mathrm{Zn} \mathrm{[38],} \mathrm{and}>59$ to 92 $\mathrm{mg} / \mathrm{kg}$ for $\mathrm{Cu}$ [39]. The toxicity concentration of $\mathrm{Zn}, \mathrm{Cu}, \mathrm{Fe}$ and $\mathrm{Mn}$ are $\mathrm{pH}$ dependent and likely to occur in acid [40] and waterlogged soils [41]. However, two farms, one from Hombolo (Bwawani 2) and another from Ihumwa (Shuleni 4) had low $\mathrm{Zn}$ of $<1.0 \mathrm{mg} / \mathrm{kg}$ and low $\mathrm{Fe}$ of $<4.5 \mathrm{mg} \mathrm{Fe} / \mathrm{kg}$ (Table 5) according to [42]. The rest of the farms have $\mathrm{Zn}, \mathrm{Cu}, \mathrm{Fe}$, and $\mathrm{Mn}$ adequate for vegetable production and yields.

The micronutrient concentration of a soil is a function of inherent soil parent materials, chemical properties and management practices. The differences in $\mathrm{Zn}$, $\mathrm{Fe}$ and $\mathrm{Cu}$ concentrations between Kilombero and Dodoma farms can be explained by the differences in soil types and soil properties. Kilombero soils have higher $\mathrm{Zn}, \mathrm{Cu}$, and Fe concentrations than Dodoma soils due to soil parent ma- 
terials and lower $\mathrm{pH}$. However, the fact that the literature reported low $\mathrm{Zn}$ in Kilombero soils due to continuous cropping for long time without $\mathrm{Zn}$ fertilization [43] [44], the sufficient $\mathrm{Zn}$ in vegetable-growing soils is due to management practices that add $\mathrm{Zn}$ to the soil. A study in typical soils of Dodoma showed low $\mathrm{Zn}$ and $\mathrm{Fe}$ in representative soils of Hombolo and Ihumwa soil profiles [22], further confirming the significance of management practices in increasing micronutrient concentrations in these vegetable-growing soils. These practices include use of FYM, rice husks and wood chips in vegetable gardens. Low to marginal Fe concentration of 3.7 to 7.5 in many sites of Dodoma shows that $\mathrm{Fe}$ availability is low. Low availability of Fe in these soils is partly contributed by high soil $\mathrm{pH}$ of $>7$, which precipitates Fe to a hydroxyl complex of Fe which is not available to plants while it is the soluble form of $\mathrm{Fe}$, cationic $\mathrm{Fe}^{2+}$ and $\mathrm{Fe}^{3+}$, that is plant-available [45]. Thus, for these high $\mathrm{pH}$ soils, foliar fertilization with Fe containing fertilizers and use of FYM will enhance Fe nutrition and vegetable yields in Dodoma. Farm yard manure provides organic compounds that chelate micronutrients, thereby shielding the nutrients from hydrolysis and precipitation reactions and improving their uptake by plants.

\subsection{Micronutrient Profiles and Health Implications of Vegetables Grown in Kilombero, Hombolo and Ihumwa, Tanzania}

\subsubsection{Zinc}

Zinc is one of the essential mineral elements for human health that are supplied through vegetables in diets. Across all sites and vegetable types, vegetable zinc contents ranged from 12.57 to $134.54 \mathrm{mg} / \mathrm{kg}$ (Table 5). On average, $\mathrm{Zn}$ content was lowest in vegetables grown in Hombolo $(29.10 \mathrm{mg} \mathrm{Zn} / \mathrm{kg})$ and highest in vegetables grown in Ihumwa (98.44 $\mathrm{mg} \mathrm{Zn/kg}$ ) (Table 5). The zinc contents in leafy vegetables in this study are higher than the $\mathrm{Zn}$ contents of leafy vegetables obtained from Poland markets, which were reported to have an average range of 23.8 in cabbage and $65 \mathrm{mg} \mathrm{Zn} / \mathrm{kg}$ in lettuce [46]. Another study involving non-leafy vegetables reported $\mathrm{Zn}$ concentrations of 0.074 to $4.75 \mathrm{mg} / \mathrm{kg}$ in Bandladesh, which are lower than the Zn levels in the present study. Another study reported average $\mathrm{Zn}$ concentrations in vegetables in industrial areas of Bangladesh to range from 19.54 to $42.06 \mathrm{mg} / \mathrm{kg}$ [17]. The $\mathrm{Zn}$ contents in leafy vegetables from Kilombero and Ihumwa are high, which could be due to use of manure and possibly application of foliar fertilizers containing $\mathrm{Zn}$.

The vegetables from Kilombero and Ihumwa are capable of supplying the recommended maximum allowable $\mathrm{Zn}$ intake of $20 \mathrm{mg}$ /day for adults [47] based on the $\mathrm{Zn}$ concentration and assumption that the daily intake of vegetables in many Tanzanian communities do not exceed $400 \mathrm{~g}$ (dry weight) per person per day. Although some vegetables in Ihumwa had higher $\mathrm{Zn}$ concentration $(>50$ $\mathrm{mg} / \mathrm{kg}$ ) that can supply more than maximum allowable $\mathrm{Zn}$ intake of $20 \mathrm{mg} /$ day but none of them supply $\mathrm{Zn}$ above daily intake of $60 \mathrm{mg} \mathrm{Zn/day.} \mathrm{The} \mathrm{adverse}$ health effects due to excessive $\mathrm{Zn}$ intake can occur at $\mathrm{Zn}$ intakes of 450 to 660 $\mathrm{mg} \mathrm{Zn} /$ day, resulting in low $\mathrm{Cu}$ absorption and ceruloplasmin level and anemia, 
Table 5. Micronutrient concentrations in different vegetables grown in Kilombero, Hombolo and Ihumwa, Tanzania.

\begin{tabular}{|c|c|c|c|c|c|c|}
\hline \multirow{2}{*}{ Site } & \multirow{2}{*}{ Farm ID } & \multirow{2}{*}{ Vegetable type } & $\mathrm{Zn}$ & $\mathrm{Cu}$ & $\mathrm{Fe}$ & $\mathrm{Mn}$ \\
\hline & & & \multicolumn{4}{|c|}{$\mathrm{mg} / \mathrm{kg}$} \\
\hline \multirow[t]{6}{*}{ Kilombero } & Mgudeni 1 & Chinese cabbage (Brassica chinensis L.) & 70.14 & 0.08 & 1230.78 & 36.06 \\
\hline & Mgudeni 2 & Sweet potato leaves (Ipomea batatas L.) & 12.57 & 0.08 & 254.64 & 35.10 \\
\hline & Mgudeni 3 & Amaranths (Amaranthus hybridus L.) & 65.67 & 0.08 & 970.06 & 72.93 \\
\hline & Mang'ula 1 & Kale (Brassica oleracea L.) & 49.53 & 0.08 & 1780.60 & 42.30 \\
\hline & Mangula 2 & Amaranths (Amaranthus hybridus L.) & 34.32 & 0.07 & 319.57 & 51.87 \\
\hline & & Mean & 46.45 & 0.08 & 911.13 & 47.65 \\
\hline \multirow[t]{8}{*}{ Hombolo } & Bwawani 1 & Sweet potato leaves (Ipomea batatas L.) & 29.20 & 14.17 & 158.85 & 22.18 \\
\hline & Bwawani 2 & Chinese cabbage (Brassica chinensis L.) & 13.14 & 6.67 & 569.86 & 87.77 \\
\hline & Bwawani 3 & Swiss chard (Beta vulgaris subsp vulgaris) & 25.08 & 11.17 & 276.84 & 90.64 \\
\hline & Bwawani 4 & Kale (Brassica oleracea L.) & 18.26 & 4.87 & 152.95 & 44.68 \\
\hline & Bwawani 5 & Chinese cabbage (Brassica chinensis L.) & 30.55 & 5.92 & 324.04 & 92.32 \\
\hline & Zepisa 1 & Amaranths (Amaranthus hybridus L.) & 51.02 & 7.27 & 254.20 & 89.44 \\
\hline & Ipala & Chinese cabbage (Brassica chinensis L.) & 36.45 & 5.77 & 184.41 & 102.13 \\
\hline & & Mean & 29.10 & 7.97 & 274.45 & 75.59 \\
\hline \multirow[t]{11}{*}{ Ihumwa } & Chididimo 1 & Kale (Brassica oleracea L.) & 91.90 & 12.58 & 714.202 & 137.17 \\
\hline & Chididimo 2 & Mnavu (Solanum nigram L.) & 100.43 & 37.36 & 861.27 & 122.78 \\
\hline & Chididimo 3 & Amaranths (Amaranthus hybridus L.) & 134.54 & 32.85 & 1660.29 & 117.99 \\
\hline & Chididimo 4 & Swiss chard (Beta vulgaris subsp vulgaris) & 85.86 & 30.60 & 581.86 & 151.56 \\
\hline & Chididimo 5 & Chinese cabbage (Brassica chinensis L.) & 106.47 & 52.37 & 655.39 & 143.17 \\
\hline & Shuleni 1 & Amaranths (Amaranthus hybridus L.) & 110.09 & 20.84 & 1395.59 & 135.97 \\
\hline & Shuleni 2 & Sweet potato leaves (Ipomea batatas L.) & 57.78 & 18.59 & 905.39 & 321.82 \\
\hline & Shuleni 3 & Sweet potato leaves (Ipomea batatas L.) & 58.14 & 14.83 & 660.29 & 289.45 \\
\hline & Shuleni 4 & Chinese cabbage (Brassica chinensis L.) & 119.26 & 12.58 & 1655.39 & 140.77 \\
\hline & Shuleni 5 & Kale (Brassica oleracea L.) & 118.91 & 13.33 & 1429.90 & 188.73 \\
\hline & & Mean & 98.44 & 24.60 & 1051.96 & 174.94 \\
\hline
\end{tabular}

while $\mathrm{Zn}$ ingestion of 4000 to $8000 \mathrm{mg} \mathrm{Zn}$ is toxic to humans [2]. However, such adverse risks in human health due to excessive $\mathrm{Zn}$ intake is unlikely to occur for $\mathrm{Zn}$ supply through food, because $\mathrm{Zn}$ is bound in food components [47]. On the other hand, all vegetables from Hombolo and vegetable from Mgudeni 2 in Kilombero cannot supply sufficient $\mathrm{Zn}$ intake for human health, and may pose risks of $\mathrm{Zn}$ deficiencies in humans. [2] reported that an average daily $\mathrm{Zn}$ intake of 5.2 to $7.9 \mathrm{mg} /$ day is low and can result in risks of $\mathrm{Zn}$ deficiencies in children to the extent that $\mathrm{Zn}$ fortification would be necessary. The present results showed variable $\mathrm{Zn}$ concentrations due to differences in management practices and not necessarily due to soil levels per se. However, most $\mathrm{Zn}$ levels in the studied vegetables would not exceed the maximum allowable daily intake of $\mathrm{Zn}$, and $14 \%$ of vegetables studied are likely to pose risks of $\mathrm{Zn}$ deficiencies, espe- 
cially if low absorption of about $15 \%$ [5] is considered.

\subsubsection{Copper}

The $\mathrm{Cu}$ content in leafy vegetables studied ranged from 0.07 to $52.37 \mathrm{mg} / \mathrm{kg}$ (Table 5). The $\mathrm{Cu}$ contents in all vegetables grown in Kilombero were very low $(<0.10 \mathrm{mg} / \mathrm{kg})$, which is lower than the sufficiency level range of 5 to $10 \mathrm{mg} / \mathrm{kg}$ for many leafy vegetables growth and yield [48]. The $\mathrm{Cu}$ concentrations in vegetables from Hombolo ranged from 5.77 to $30.55 \mathrm{mg} / \mathrm{kg}$ while those from Ihumwa ranged from 12.58 to 52.37 (Table 5). The cupper concentrations in vegetables from Hombolo and Ihumwa are above the critical level for plant growth and yield [48]. Most of the vegetables in Ihumwa and Hombolo are below the critical levels for phyto-toxicity of $19.40 \mathrm{mg} / \mathrm{kg}$ for Chinese cabbage (medium sensitive to $\mathrm{Cu}$ phyto-toxicity) to $30.9 \mathrm{mg} / \mathrm{kg}$ for Celery (tolerant to $\mathrm{Cu}$ phyto-toxicity) that would cause $10 \%$ reduction in dry matter yield [39].

The $\mathrm{Cu}$ concentrations of vegetables from Kilombero are insufficient for vegetable growth and yield and may contribute to low vegetable yields in these areas. Similarly, balanced $\mathrm{Cu}$ nutrition in humans requires a $\mathrm{Cu}$ intake of at least $2.4 \mathrm{mg} /$ day for a net $\mathrm{Cu}$ gain, while intake of $<0.8 \mathrm{mg} /$ day results in net losses of $\mathrm{Cu}$ [49]. Thus, people consuming the vegetables from Kilombero will have low $\mathrm{Cu}$ intake, below $0.8 \mathrm{mg} /$ day (for $400 \mathrm{~g}$ vegetables per day), and may require supplementation of $\mathrm{Cu}$ from other types of diets especially meat-based diet. A review by [50] reported the maximum allowable concentration (MAC) of $\mathrm{Cu}$ from vegetables to be $40 \mathrm{mg} / \mathrm{kg}$ (fresh weight, $\mathrm{fw}$ ). In the present study all vegetable samples did not exceed the MAC (Table 2). Reference [51] reported Cu concentrations in non-leafy vegetables of Bangladesh to range from 0.946 to 11.78 $\mathrm{mg} / \mathrm{kg}(\mathrm{fw})$, which is slightly higher than the $\mathrm{Cu}$ concentrations in leafy vegetables from Kilombero and Hombolo, but lower than the $\mathrm{Cu}$ concentrations in vegetables from Ihumwa.

A study conducted in Morogoro region a decade ago reported $\mathrm{Cu}$ contents in vegetables ranging from 8.85 to $13.5 \mathrm{mg} / \mathrm{kg}$ [52], which are similar to $\mathrm{Cu}$ concentrations of vegetables from Hombolo, but lower than those from Ihumwa. All $\mathrm{Cu}$ concentrations of all vegetables in this study are lower than the Potential Dietary Toxicity (PDT) due to $\mathrm{Cu}$ of $338.98 \mathrm{mg} / \mathrm{kg}$ [39]. A recent review on the $\mathrm{Cu}$ requirement for human health reported limited evidence on health and impairment of various physiological/metabolic functions such as cardiovascular diseases, reduced cognitive ability, arthritis, and cancer for $\mathrm{Cu}$ intake range of 0.6 to $3.0 \mathrm{mg} /$ day and low immunity due to $\mathrm{Cu}$ intake range of $<0.38 \mathrm{mg} /$ day, suggesting further studies on $\mathrm{Cu}$ requirements [49]. Therefore, vegetables from Hombolo and Ihumwa can provide sufficient $\mathrm{Cu}$ for human health. However, vegetables from Kilombero are deficient in $\mathrm{Cu}$ for plant growth and may not be able to supply sufficient $\mathrm{Cu}$ for good human health.

\subsubsection{Iron}

Iron contents of vegetables grown in Dodoma and Kilombero ranged from 152.95 to $1780 \mathrm{mg} / \mathrm{kg}$, and averaged $911.13 \mathrm{mg} / \mathrm{kg}$ (Table 5). Vegetables grown 
in soils from Ihumwa had higher average Fe contents ranging from 581.86 to 1655.39 , with mean of $1051 \mathrm{mg} / \mathrm{kg}$, than those from Kilombero and those from Hombolo. Vegetables from Hombolo contained Fe contents ranging from 152.95 to $569.86 \mathrm{mg} / \mathrm{kg}$, with a mean of $274.45 \mathrm{mg} \mathrm{Fe} / \mathrm{kg}$ (Table 5). Among vegetables, Chinese cabbage, kale and Amaranthus had higher Fe contents than other leafy vegetables across the soils (Table 5) and management practices.

All vegetables contain sufficient Fe for human diets, with recommended nutrient intake (RNI) for Fe for adults being $27.4 \mathrm{mg} /$ day for males to $58.8 \mathrm{mg} / \mathrm{day}$ for females [2], obtained with maximum vegetable intake of $400 \mathrm{~g} /$ day. All vegetables from the garden soils studied have sufficient Fe contents for growth and yield. In many vegetables $\mathrm{Fe}$ contents of 50 to $300 \mathrm{mg} / \mathrm{kg}$ are considered sufficient for leafy vegetable growth and adequate yield [48]. The present adequate levels of $\mathrm{Fe}$ in vegetables is supported by the soil Fe levels and management practices. The relatively lower Fe contents in Kilombero vegetables than in Ihumwa vegetables despite adequate $\mathrm{pH}$ for micronutrient availability may be due to low use of organic manure in Kilombero as reported by [36]. This shows the important role of manure in enhancing Fe availability over the soil Fe content per se. Ihumwa farmers apply more manure in their vegetable gardens than do Kilombero farmers [36].

Vegetables are a dependable source of Fe especially in poor families, due to higher $\mathrm{Fe}$ contents and availability of $\mathrm{Fe}$ from vegetables. Many vegetables contain ascorbic acid which enhances Fe bioavailability in the gastrointestinal tract [11], unlike cereals diets, which contain high phytate that inhibits Fe bioavailability. However, health benefits of phytate have also been reported, such as reduced risks of non-communicable diseases like various cancers, heart-related disease, diabetes and renal stones [53]. Thus, combinations of vegetables and cereals in the diet will ensure both health benefits of protection against non-communicable diseases and increase Fe bioavailability to humans.

\subsubsection{Manganese}

Manganese contents in the vegetables studied ranged from 22.18 to 321.82 $\mathrm{mg} / \mathrm{kg}$ (Table 5). The vegetables from Hombolo and Ihumwa have generally higher Mn concentrations, averaging 75.59 and $174 \mathrm{mg} / \mathrm{kg}$, respectively, than the vegetables from Kilombero with average Mn contents of $47.65 \mathrm{mg} / \mathrm{kg}$ (Table 5). The Mn content in all vegetables is within the sufficiency range of 50 to 200 $\mathrm{mg} / \mathrm{kg}$ for adequate growth and yield of leafy vegetables as reported by [48]. One vegetable from Bwawani1 had a lower Mn content of $22.18 \mathrm{mg} / \mathrm{kg}$, while two vegetables from Shuleni 1 and Shuleni 2 had higher Mn contents of 321.82 and $289.45 \mathrm{mg} / \mathrm{kg}$, than the sufficiency levels (Table 5). However, none of the $\mathrm{Mn}$ contents in vegetables reached the Mn toxicity levels of $1940 \mathrm{mg} / \mathrm{kg}$ reported by [54].

Manganese is an essential nutrient for both plants and humans. The Mn contents in vegetables in this study are adequate for plant growth and yield. While no established recommended dietary intake of $\mathrm{Mn}$ has been reported due to insufficient information, the MAC for Mn is $11 \mathrm{mg} / \mathrm{kg}$ for adults and $6 \mathrm{mg} /$ day for 
children below 13 years old [55]. The Mn levels in vegetables studied are lower than the $200 \mathrm{mg} / \mathrm{kg}$ Mn content in lettuce leaves and $290 \mathrm{mg} / \mathrm{kg}$ Mn concentration in beans leaves grown in contaminated soils of Germany [56], except for sweet potato leaves from two sites in Ihumwa. The Mn levels in the vegetables presently studied supply higher than the MAC of $11 \mathrm{mg} \mathrm{Mn/day} \mathrm{for} \mathrm{adults,} \mathrm{as-}$ suming $400 \mathrm{~g}$ of vegetables are consumed per day. Although the human body has a mechanism of excreting excess $\mathrm{Mn}$ from the body, the possibility of side effects due to excessive $\mathrm{Mn}$ intake is reported in populations with Fe-deficient anemia [55]. A study conducted in Bagladesh reported a median concentration of $\mathrm{Mn}$ in vegetables to be $65 \mathrm{mg} / \mathrm{kg}$ [57]. Manganese toxicity in human due to food intake per se is rare despite the fact that some diets supply more than $20 \mathrm{mg} /$ day of manganese [55]. Rare Mn toxicity due to diet is due to homeostatic mechanism to regulate absorption and excretion [55] [58]. Therefore, the vegetables studied have enough $\mathrm{Mn}$ for human health, and if sufficient vegetables are consumed in everyday meal, Mn supplementation may not be needed in these areas.

\subsection{Effects of Soil Fertility Management on Soil Properties and Vegetable Mineral Nutrient Concentrations}

\subsubsection{Differences in Soil Properties due to Soil Fertility Management}

Soil fertility management practices influence soil properties and hence nutrient uptake by plants, which eventually determine the quality of vegetables in terms of their nutrient contents. In this study, the common soil fertility management practices in vegetable production in Kilombero include use of farm yard manure alone (FYM), FYM and inorganic fertilizers (usually Urea and CAN) and use of FYM and compost from available organic materials such as rice husks. The results show that different fertility management practices used in the study areas resulted in significant differences in soil properties, especially soil TN, available $\mathrm{P}, \mathrm{Zn}$ and $\mathrm{Cu}$ in Kilombero and Hombolo soils (Table 6). In Ihumwa, soil fertility management practices resulted in significant differences in soil $\mathrm{K}, \mathrm{Cu}, \mathrm{Fe}$ and Mn (Table 6). Compost and rice husks used in Kilombero for soil fertility management in vegetable production resulted in significantly the highest soil $\mathrm{N}$ (0.3\%), P (133.8 mg/kg), and Zn (29.3 mg/kg) (Figure 4). Soil available P and Cu in soils treated with FYM alone did not statistically differ from that of soils treated with compost and rice husks. Soils in Kilombero treated with FYM + urea had the lowest soil total N, P, $\mathrm{Zn}$ and $\mathrm{Cu}$ (Figure 4).

Table 6. Analysis of Variance summary to show effects of soil fertility management on nutrient concentrations in soils from Mang'ula, Hombolo and Ihumwa, Tanzania.

\begin{tabular}{|c|c|c|c|c|c|c|c|c|}
\hline \multirow{2}{*}{ Source of Variation } & \multirow{2}{*}{ df } & Soil N & Soil P & Soil K & Soil Zn & Soil Cu & Soil Fe & Soil Mn \\
\hline & & \multicolumn{7}{|c|}{$p$-value } \\
\hline Hombolo-Fertility management & 2 & $0.0103^{*}$ & $0.0223^{*}$ & ns & $0.0005^{\star}$ & $0.0009^{*}$ & ns & ns \\
\hline Ihumwa-Fertility management & 2 & ns & ns & $0.0034^{*}$ & ns & $0.0164^{*}$ & $0.0004^{*}$ & $0.0120^{*}$ \\
\hline
\end{tabular}

$\mathrm{df}=$ degrees of freedom; ${ }^{*}=$ significant at alpha $=0.05 ; \mathrm{ns}=$ not significant at alpha $=0.05$. 

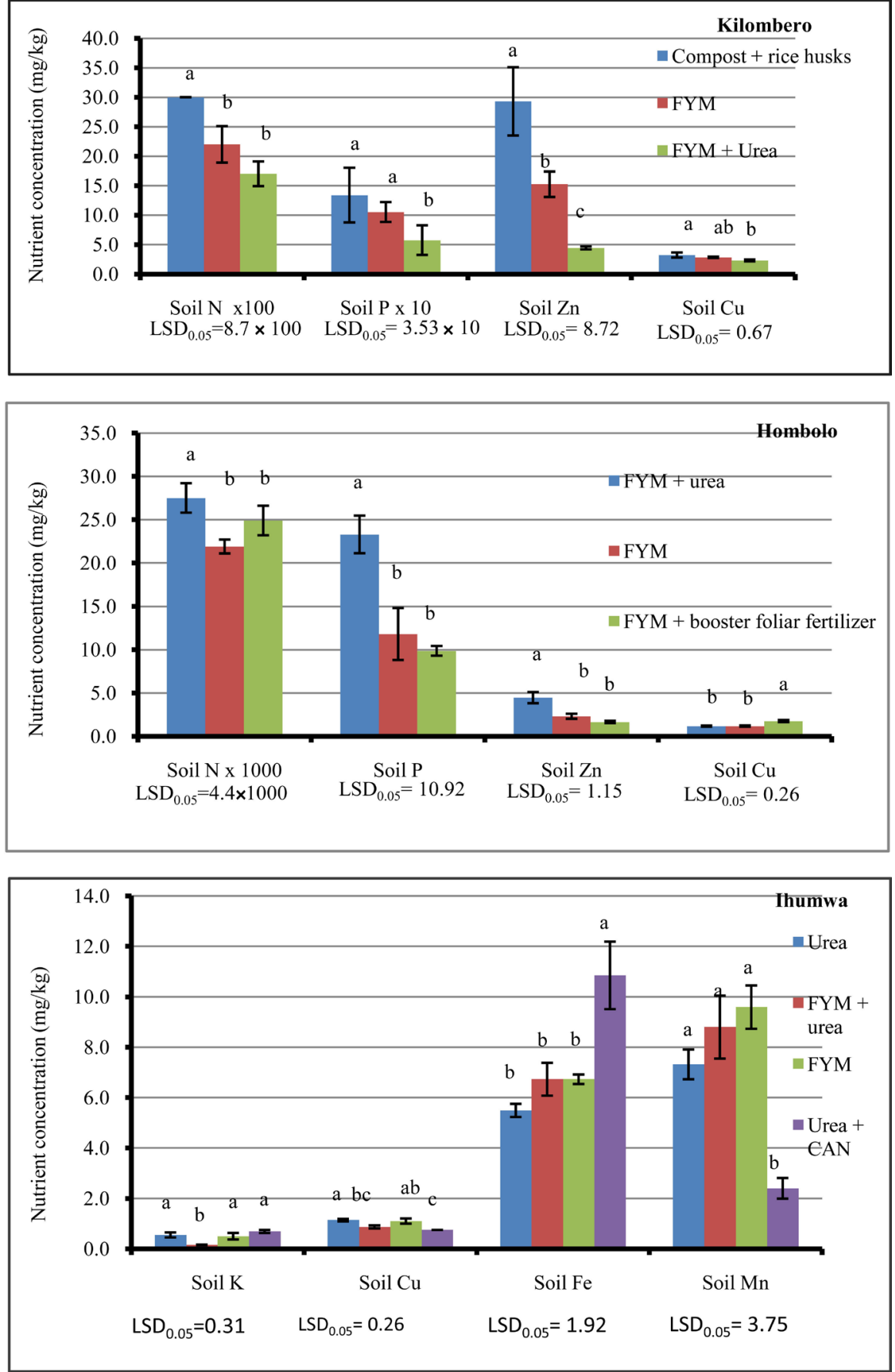

Figure 4. Effects of soil fertility management on nutrient concentrations in vegetable-growing soils of Kilombero, Hombolo and Ihumwa, Tanzania. Columns within the soil nutrient followed by same letter are not statistically different at alpha $=0.05 . \mathrm{LSD}_{0.05}=$ Least significant difference at alpha $=0.05$; Error bars $=$ Standard error of means; FYM $=$ farm yard manure; $\mathrm{CAN}=$ Calcium Ammonium Nitrate $(26-0-0+19 \% \mathrm{Ca}) ; \mathrm{N}=$ nitrogen; $\mathrm{P}=$ phosphorus $\mathrm{K}=$ potassium $; \mathrm{Zn}=$ zinc $; \mathrm{Cu}=$ copper $; \mathrm{Fe}=$ iron; $\mathrm{Mn}=$ manganese.

In Hombolo, the fertility management practices included application of FYM + Urea, FYM alone, or FYM + foliar fertilizers. The results showed that among these practices FYM + urea resulted in higher soil total $\mathrm{N}(2.8 \%)$, available $\mathrm{P}$ $(23.3 \mathrm{mg} / \mathrm{kg})$ and $\mathrm{Zn}(4.5 \mathrm{mg} / \mathrm{kg})$ than other management practices. However, 
FYM + urea had significantly the lowest available $\mathrm{Cu}(1.2 \mathrm{mg} / \mathrm{kg})$ in soil (Figure 4). Farm yard manure + foliar fertilizers resulted in statistically similar soil nutrient concentrations, but resulted in significantly greater $\mathrm{Cu}(1.8 \mathrm{mg} / \mathrm{kg})$ concentration in soil (Figure 4).

In Ihumwa site, the common management practices consisted of the use of urea alone, FYM + urea, FYM alone or Urea + CAN. The results showed that soil $\mathrm{K}$ was significant $(\mathrm{p}<0.05)$ lowest $\left(0.16 \mathrm{cmol}_{\mathrm{c}} / \mathrm{kg}\right)$ in soils managed by FYM + urea compared to soil $\mathrm{K}$ in other management practices (ranged from 0.50 $\mathrm{cmolc} / \mathrm{kg}$ in FYM alone to $0.69 \mathrm{cmol}_{\mathrm{c}} / \mathrm{kg}$ in Urea+CAN) (Figure 4). Soil Cu was lowest $(0.75 \mathrm{mg} / \mathrm{kg})$ in soils managed by use of urea + CAN (Figure 4). Urea alone, FYM + urea, and FYM alone had statistically similar soil available Mn (range 7.32 to $9.59 \mathrm{mg} / \mathrm{kg}$ ), and $\mathrm{Fe}$ (5.49 to $6.73 \mathrm{mg} / \mathrm{kg}$ ) (Figure 4). Urea + CAN resulted in significantly the lowest $\mathrm{Mn}$ of $2.40 \mathrm{mg} / \mathrm{kg}$ and the highest soil available Fe of $10.85 \mathrm{mg} / \mathrm{kg}$ (Figure 4).

Soil fertility management practices slightly differed among the three sites studied, but the use of FYM and FYM in combination with inorganic $\mathrm{N}$ fertilizer were common practices. The soil fertility management effects on soil nutrient status differed among sites due to differences in inherent soil properties among these sites. Reference [22] described the soils of Ihumwa and Hombolo as Haplic Cambisol and Haplic cutanic Acrisols, respectively, with very low P, Ca and Zn, while [17] described Kilombero soils as alluvial clay soil with low to medium Zn, $\mathrm{P}$ and $\mathrm{K}$ in some locations. Thus, fertility management with addition of $\mathrm{P}, \mathrm{Zn}$, $\mathrm{Fe}$, and $\mathrm{Mn}$ increased concentrations of these nutrients in the Ihumwa and Hombolo soils. Likewise, high total $\mathrm{N}$, available $\mathrm{P}$, and $\mathrm{Zn}$ due to compost and rice husks use is due to high contents of $\mathrm{N}, \mathrm{P}, \mathrm{Zn}$ in rice husks and compost, and slow release of these nutrients from these organic materials used in Kilombero vegetable growing soils. These results further suggest that $\mathrm{Zn}$ and $\mathrm{Cu}$ in these soils following use of are slightly lower than from the use of compost and rice husks.

In Hombolo, the high soil total N, P, and Zn suggest that the FYM is the major source of $\mathrm{N}, \mathrm{P}$ and $\mathrm{Zn}$ in the soil, because these soils are naturally very low in $\mathrm{N}, \mathrm{P}$ and $\mathrm{Zn}$ [22]. However, the P concentrations in soils under all fertility management practices in Hombolo were still lower than the critical level of $15 \mathrm{mg} / \mathrm{kg}$ [32]. Urea supplemented available $\mathrm{N}$, which enhanced plant growth and absorption of other nutrients. It is therefore beneficial to integrate the two sources of nutrients. Higher total $\mathrm{N}$ in Hombolo compared to Kilombero is due to differences in leaching and runoff potential, where lower rains in Hombolo may have resulted in less leaching hence higher total $\mathrm{N}$ than in soils from Kilombero where rains are high.

Ihumwa soil is deficient in soil $\mathrm{K}$ (Table 4; [22]), hence low $\mathrm{K}$ in the soil under FYM + Urea, which is lower than the critical K level of $0.20 \mathrm{cmolc} / \mathrm{kg}$ [59] [32]. Low K in FYM + Urea treated soil may be due to low quantity of manure used when combined with urea. In the other management practices soil $\mathrm{K}$ is high and it appears that $\mathrm{K}$ is supplied by organic manure except for Urea + CAN. Low 
$\mathrm{Cu}$ due to use of Urea + CAN may be explained by non-addition of $\mathrm{Cu}$ under this practice and possible antagonistic effect of divalent cation $\mathrm{Ca}$ on $\mathrm{Cu}$. This practice's lowest $\mathrm{Cu}$ in soils corresponds to numerically lowest $\mathrm{Cu}$ concentration in vegetables from Ihumwa, which was $13.33 \mathrm{mg} / \mathrm{kg}$ as compared to $43.33 \mathrm{mg} / \mathrm{kg}$ from FYM + Urea and $35.11 \mathrm{mg} / \mathrm{kg}$ from Urea alone (data not shown).

Higher $\mathrm{Cu}$ concentration in soil but lower $\mathrm{Cu}$ concentration in vegetables due to FYM alone may be due to supply of $\mathrm{Cu}$ from FYM, and organic matter interference with $\mathrm{Cu}$ uptake. It was established that $\mathrm{Cu}$ uptake is reduced by SOM because $\mathrm{Cu}$ is tightly bound by OM [60]. High soil Fe in the Urea + CAN practice, which corresponds to the highest Fe concentration in vegetables (1429.9 $\mathrm{mg} / \mathrm{kg}$ ), cannot be presently explained. Also the lowest soil Fe in soils supplied with Urea alone cannot be directly explained, suggesting presence of complex factors affecting soil $\mathrm{Fe}$ and/or other sources of Fe in soil, which were not captured in this study. The differences in soil nutrient contents due to different management practices can also be explained by differences in inherent soil properties due to parent materials of soils in Kilombero, Hombolo and Ihumwa.

\subsubsection{Effects of Soil Fertility Management on Nutrient Concentrations in Vegetables}

The analysis of variance results showed that none of the micronutrients $(\mathrm{Cu}, \mathrm{Fe}$, $\mathrm{Zn}$ and $\mathrm{Mn}$ ) concentrations in vegetables were significantly affected by soil fertility management practices. Soil fertility management practices resulted in significant differences in $\mathrm{P}, \mathrm{K}$ and $\mathrm{Mg}$ concentrations in vegetables from Kilombero, $\mathrm{N}$ concentration in vegetables from Hombolo, and $\mathrm{K}$ and $\mathrm{Ca}$ in vegetables from Ihumwa (Table 7). All other macronutrients did not differ significantly among soil fertility management practices in all sites. In Kilombero, vegetables grown in soils that received compost + rice husks had significantly the highest $\mathrm{P}$ (0.73\%), K (5.51\%) and $\mathrm{Mg}(0.25 \%)$ levels (Figure 5). Kilombero vegetables grown in soils that received FYM alone and FYM + Urea had P levels ranging from $0.54 \%$ to $0.61 \%$, $\mathrm{K}$ from $3.76 \%$ to $5.19 \%$ and $\mathrm{Mg}$ from $0.09 \%$ to $0.13 \%$ (Figure 5). Vegetables from Hombolo had the highest concentration of $\mathrm{N}(3.58 \%)$ when FYM + urea were applied as compared to when FYM alone was used $(2.48 \%$ $\mathrm{N})$ and FYM + foliar fertilizer were applied $(2.46 \% \mathrm{~N})$ (Figure 5). Vegetables from Ihumwa had the highest $\mathrm{K}(3.08 \%)$ when Urea alone was applied and the highest Ca concentration (1.63\%) when Urea + CAN were applied (Figure 5).

Table 7. Analysis of variance summary to show the effects of soil fertility management on nutrient concentration in vegetables grown in soils from Kilombero, Hombolo and Ihumwa, Tanzania.

\begin{tabular}{|c|c|c|c|c|c|c|}
\hline \multirow{2}{*}{ Source of Variation } & \multirow{2}{*}{$\mathrm{df}$} & Vegetable $\mathrm{N}$ & Vegetable P & Vegetable K & Vegetable Mg & Vegetable Ca \\
\hline & & \multicolumn{5}{|c|}{$p$ value } \\
\hline Kiombero-Fertility management & 2 & ns & $0.0193^{*}$ & $0.0040^{*}$ & $0.0001^{*}$ & ns \\
\hline Hombolo-Fertility management & 2 & $0.0080^{*}$ & ns & ns & ns & ns \\
\hline Ihumwa-Fertility management & 2 & ns & ns & $0.0011^{*}$ & ns & $0.0086^{*}$ \\
\hline
\end{tabular}

$\mathrm{df}=$ degrees of freedom; ${ }^{*}=$ significant at alpha $=0.05 ; \mathrm{ns}=$ not significant at alpha $=0.05$. 

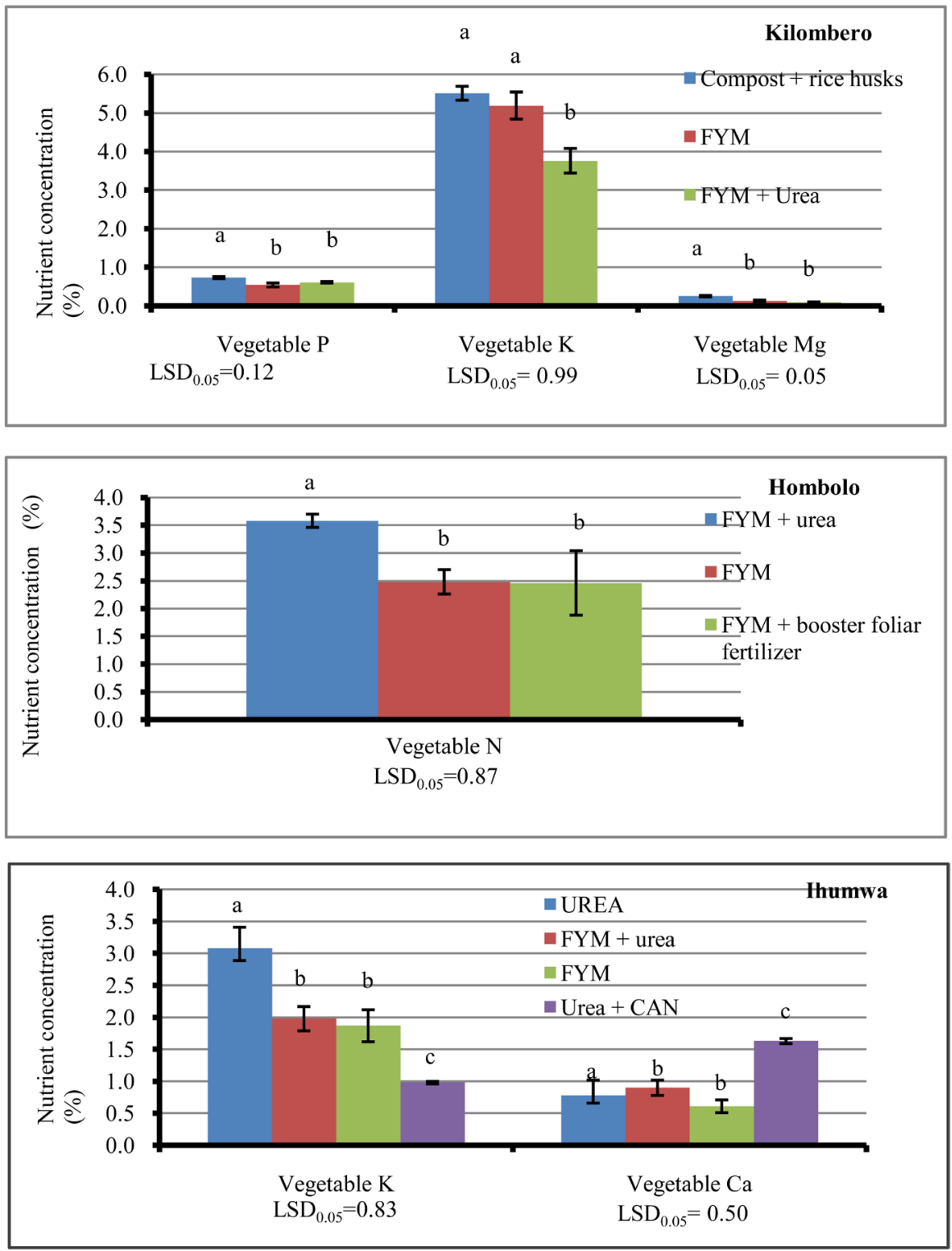

Figure 5. Effect of soil fertility management on nutrient concentrations in vegetables grown in Kilombero, Hombolo and Ihumwa, Dodoma, Tanzania. Columns within the soil nutrient followed by same letter are not statistically different at alpha $=0.05$. LSD $=$ Least significant difference at alpha $=0.05$; Error bars = Standard error of means; FYM = farm yard manure; CAN = Calcium Ammonium Nitrate $(23-0-0+\% \mathrm{Ca}) ; \mathrm{N}=$ nitrogen; $\mathrm{P}$ = phosphorus; $\mathrm{K}=$ potassium $; \mathrm{Zn}=$ zinc $; \mathrm{Cu}$-copper $; \mathrm{Fe}=$ iron; $\mathrm{Mn}=$ manganese.

The results showed that management practices directly influenced the absorption of macronutrients and hence nutrient concentrations. The SFMP effect differed among sites due to differences in soil physical and chemical properties. The higher concentrations of $\mathrm{P}, \mathrm{K}$, and $\mathrm{Mg}$ in vegetables that received compost + rice husks in Kilombero are due to higher concentration of these nutrients in rice husks than under the other fertility management practices. Higher $\mathrm{N}$ in Hombolo vegetables due to FYM + Urea suggests better supply of $\mathrm{N}$ when organic and inorganic $\mathrm{N}$ sources are combined in these sandy loam soils with low SOM [22]. While Urea supplies a high quantity of readily available N, FYM re- 
leases $\mathrm{N}$ slowly and builds up SOM which reduces leaching losses, hence better $\mathrm{N}$ uptake by vegetables. The management practices used in Hombolo and Ihumwa did not lead to differences in $\mathrm{P}$ concentration in vegetables despite the fact that there were soil P differences (Figure 4), suggesting that the SFMP used had low ability to supply P. In addition, soils of Ihumwa and Hombolo are also inherently low in P. Thus, lack of significant effects of fertility management practices on vegetable $\mathrm{P}$ concentration in Hombolo and Ihumwa may be due the inherently low $\mathrm{P}$ in these soils.

\subsection{Relationships between Soil and Vegetable Mineral Nutrient Concentrations}

To determine the relationship between soil properties and nutrient concentration in vegetables, the soil properties were pulled across all fertility management practices to obtain sufficient observations for correlation and regression analysis. Due to differences in agro-ecological conditions and soil types among studied sites, the relationship between soil properties and plant nutrients were investigated separately by site. This approach was expected to reduce wide variations, and allow understanding of soil-plant processes that can be explored to enhance micronutrients quality of vegetables and understanding the how micronutrient concentration in soils affect mineral quality of vegetables.

\subsubsection{Relationships between Soil Properties and Nutrient Concentrations in Vegetables from Kilombero}

In Kilombero soils with soil $\mathrm{Zn}$ concentration range of 3.9 to $40.6 \mathrm{mg} / \mathrm{kg}$, soil Zn was positively correlated with $\mathrm{K}$ and $\mathrm{Mg}$ concentrations in vegetables (Table 8). Concentration of soil $\mathrm{Cu}$ ranged from 2.0 to $4.10 \mathrm{mg} / \mathrm{kg}$ and was significant and positively correlated with $\mathrm{Mg}$ (Table 8 ). On the other hand soil $\mathrm{P}$ ranged from 4.8 to $145.6 \mathrm{mg} / \mathrm{kg}$ and was significantly and positively correlated with vegetable $\mathrm{K}(\mathrm{r}=0.53, \mathrm{p}<0.05)$ and $\mathrm{Cu}(\mathrm{r}=0.54, \mathrm{p}=0.05)$ (Table 8). The soil $\mathrm{pH}$ ranged from 5.72 to 6.98 , with average of 6.41 in the Kilombero soils studied, and within this range, soil $\mathrm{pH}$ was significantly and negatively correlated with $\mathrm{Cu}$ concentration in vegetables $(\mathrm{r}=-0.645 ; \mathrm{p}<0.05)$ (Table 8). Similar negative correlation between soil $\mathrm{pH}$ and micronutrient availability, including that of $\mathrm{Cu}$, was reported by [61]. Reference [60] reported increased fixation of $\mathrm{Cu}$ in long term period with increase in $\mathrm{pH}$ in semi-arid alkaline soils of Texas, USA. Although the $\mathrm{Cu}$ concentration in soil was sufficient, the availability of $\mathrm{Cu}$ to vegetable plants was low as shown by low $\mathrm{Cu}$ concentrations in vegetables from Kilombero. Low availability of $\mathrm{Cu}$ in these soils was probably because of complex $\mathrm{Cu}$ fixation pattern in soils and influence of other soil constituents on availability of $\mathrm{Cu}$ for plant absorption. Reference [60] reported best fit of power model kinetics of $\mathrm{Cu}$ fixation in alkaline soils in the long term period but second order model in the short run, suggesting that $\mathrm{Cu}$ fixation changes over time and in the long term $\mathrm{Cu}$ fixation is nonlinear. On the other hand, in the short term, the $\mathrm{Cu}$ fixation is controlled by more than one soil property in addition to $\mathrm{Cu}$ concentration in soil [60]. The positive correlation between soil $\mathrm{P}$ and vegetable $\mathrm{K}$ and $\mathrm{Cu}$ may be 
Table 8. Descriptive statistics and correlation analysis of concentrations of selected nutrients in vegetables and soil properties in Kilombero district.

\begin{tabular}{|c|c|c|c|c|c|}
\hline \multicolumn{6}{|c|}{ Vegetables' nutrient concentrations } \\
\hline Parameter & $\mathrm{n}$ & Mean & SD & Min & Max \\
\hline $\mathrm{K}(\%)$ & 16 & 4.74 & 1.04 & 2.96 & 6.41 \\
\hline $\operatorname{Mg}(\%)$ & 16 & 0.14 & 0.08 & 0.05 & 0.29 \\
\hline $\mathrm{Cu}(\mathrm{mg} / \mathrm{kg})$ & 16 & 0.08 & 0.01 & 0.07 & 0.08 \\
\hline \multicolumn{6}{|c|}{ Soil properties } \\
\hline $\mathrm{pH}\left(\mathrm{H}_{2} \mathrm{O}\right)$ & 16 & 6.41 & 0.39 & 5.72 & 6.98 \\
\hline $\mathrm{EC}(\mathrm{dS} / \mathrm{m})$ & 16 & 0.11 & 0.06 & 0.02 & 0.30 \\
\hline CEC $(\mathrm{cmolc} / \mathrm{kg})$ & 16 & 19.41 & 5.34 & 12.40 & 33.60 \\
\hline $\mathrm{P}(\mathrm{mg} / \mathrm{kg})$ & 16 & 94.42 & 40.02 & 44.80 & 145.6 \\
\hline $\mathrm{Zn}(\mathrm{mg} / \mathrm{kg})$ & 16 & 14.70 & 11.64 & 3.90 & 40.6 \\
\hline $\mathrm{Cu}(\mathrm{mg} / \mathrm{kg})$ & 16 & 2.73 & 0.60 & 2.00 & 4.10 \\
\hline \multicolumn{6}{|c|}{ Pearson correlation coefficients $(\mathrm{r})$} \\
\hline & & Soil Zn & Soil $\mathrm{Cu}$ & Soil P & Soil pH \\
\hline Vegetable K & 16 & $0.538^{*}$ & 0.0 .451 & $0.528^{*}$ & -0.143 \\
\hline Vegetable $\mathrm{Mg}$ & 16 & $0.703^{*}$ & $0.553^{*}$ & 0.434 & -0.325 \\
\hline Vegetable $\mathrm{Cu}$ & 16 & 0.401 & 0.212 & $0.536^{*}$ & $-0.645^{\star}$ \\
\hline
\end{tabular}

$\mathrm{n}=$ number of observation; SD-standard deviation; Min $=$ minimum; Max $=$ maximum; ${ }^{\star}$ Significant at alpha $=0.05$.

due to positive effect of $\mathrm{P}$ on root growth, which increases root interception and hence absorption of $\mathrm{K}$ and $\mathrm{Cu}$ by the vegetables [62]. Another positive correlation of $\mathrm{P}$ and micronutrients was reported to occur in the presence of vesicular arbuscular mycorrhizal fungi [63]. The negative correlation between soil $\mathrm{pH}$ and $\mathrm{Cu}$ in vegetables shows that $\mathrm{Cu}$ was more available in soils with low $\mathrm{pH}(<7.0)$, which is consistent with the availability of cationic micronutrients in low $\mathrm{pH}$ as reported by [45].

\subsubsection{Relationships between Soil Properties and Nutrient Concentrations in Vegetables from Hombolo}

Nutrient concentrations in vegetables grown in Hombolo had significant and positive correlation with Soil $\mathrm{Fe}, \mathrm{CEC}$ and $\mathrm{pH}$. Concentration of $\mathrm{K}$ in vegetables was significantly and positively correlated with soil Fe concentration $(r=0.447$; $\mathrm{p}<0.05$ ) (within the soil Fe range of 3.29 to $42.50 \mathrm{mg} / \mathrm{kg}$ ) but negatively correlated with soil $\mathrm{pH}(\mathrm{r}=-0.686 ; \mathrm{p}<0.05)$ (within the soil $\mathrm{pH}$ range of 6.41 to 8.73 ) (Table 9). Zinc concentration in vegetables was negatively correlated with soil $\mathrm{pH}$ and CEC (within the CEC range of 10.8 to 24.20), with $\mathrm{r}=-0.571$ and -0.501 , respectively (Table 9).

These results shows that in soils of Hombolo the soil Fe influenced availability of $\mathrm{K}$ in vegetables, while soil $\mathrm{pH}$ influenced availability of $\mathrm{K}, \mathrm{P}$, and $\mathrm{Zn}$ in vegetables. The negative influence of $\mathrm{pH}$ on $\mathrm{P}$ and $\mathrm{Zn}$ concentrations in the vegeta- 
Table 9. Descriptive statistics and correlation analysis of concentrations selected nutrients in vegetables and soil properties in Hombolo, Dodoma Municipality.

\begin{tabular}{|c|c|c|c|c|c|}
\hline \multicolumn{6}{|c|}{ Vegetables' nutrient concentrations } \\
\hline Parameter & $\mathrm{n}$ & Mean & SD & Min & Max \\
\hline $\mathrm{K}(\%)$ & 22 & 4.143 & 1.54 & 0.38 & 6.53 \\
\hline $\mathrm{Zn}(\mathrm{mg} / \mathrm{kg})$ & 22 & 28.23 & 14.18 & 1.77 & 57.63 \\
\hline $\mathrm{Fe}(\mathrm{mg} / \mathrm{kg})$ & 22 & 316.71 & 267.37 & 17.26 & 1235.00 \\
\hline $\mathrm{Cu}(\mathrm{mg} / \mathrm{kg})$ & 22 & 8.29 & 4.93 & 1.87 & 21.66 \\
\hline \multicolumn{6}{|l|}{ Soil properties } \\
\hline $\mathrm{pH}\left(\mathrm{H}_{2} \mathrm{O}\right)$ & 22 & 8.02 & 0.60 & 6.41 & 8.73 \\
\hline $\mathrm{EC}(\mathrm{dS} / \mathrm{m})$ & 22 & 0.25 & 0.13 & 0.01 & 0.41 \\
\hline CEC (cmolc/kg) & 22 & 15.73 & 3.63 & 10.80 & 24.20 \\
\hline $\mathrm{P}(\mathrm{mg} / \mathrm{kg})$ & 22 & 15.19 & 9.93 & 3.22 & 31.71 \\
\hline $\mathrm{Zn}(\mathrm{mg} / \mathrm{kg})$ & 22 & 2.63 & 1.75 & 0.45 & 7.36 \\
\hline $\mathrm{Fe}(\mathrm{mg} / \mathrm{kg})$ & 22 & 12.66 & 8.93 & 3.29 & 42.50 \\
\hline $\mathrm{Cu}(\mathrm{mg} / \mathrm{kg})$ & 22 & 1.25 & 0.28 & 0.83 & 1.98 \\
\hline \multicolumn{6}{|c|}{ Pearson correlation coefficients (r) } \\
\hline & & Soil Zn & Soil Fe & Soil CEC & Soil pH \\
\hline Vegetable K & 22 & -0.216 & $0.447^{\star}$ & -0.162 & $-0.686^{*}$ \\
\hline Vegetable P & 22 & 0.207 & 0.407 & $-0.472^{*}$ & $-0.496^{*}$ \\
\hline Vegetable Zn & 22 & 0.026 & 0.417 & $-0.501^{\star}$ & $-0.571^{*}$ \\
\hline Vegetable Fe & 22 & $-0.439^{*}$ & -0.172 & 0.126 & -0.055 \\
\hline
\end{tabular}

$\mathrm{n}=$ number of observation; SD-standard deviation; Min = minimum; Max = maximum; ${ }^{*}$ Significant at alpha $=0.05$.

bles suggests that the high soil $\mathrm{pH}$ in Hombolo soils, with a mean $\mathrm{pH}$ of 8.08, rendered $\mathrm{P}$ and $\mathrm{Zn}$ unavailable due to $\mathrm{P}$ fixation and precipitation of $\mathrm{Zn}$ with hydroxyl ions at those high $\mathrm{pH}$ levels [45] [64]. The negative correlation between soil CEC and vegetable $\mathrm{P}$ and $\mathrm{Zn}$ concentration shows that relatively more $\mathrm{P}$ and $\mathrm{Zn}$ are available at low CEC within the range 15.73 to $24.20 \mathrm{cmolc} / \mathrm{kg}$ ). It appears that the increase in total negatively charged colloids increased cationic $\mathrm{Zn}$ adsorption, which reduced its availability especially in high $\mathrm{pH}$ soils. On the contrary, in Kilombero soils with high CEC (range of 12.4 to $33.60 \mathrm{cmolc} / \mathrm{kg}$ ) and low soil pH (5.72 to 6.98), CEC did not affect $\mathrm{P}$ and $\mathrm{Zn}$ concentrations in the vegetables. Therefore, in Hombolo, soil $\mathrm{Zn}$, soil Fe, CEC and soil pH individually or jointly influenced concentrations of $\mathrm{K}, \mathrm{P}$, and $\mathrm{Zn}$ in the vegetables.

\subsubsection{Relationships between Soil Properties and Nutrient Concentrations in Vegetables from Ihumwa}

The concentration of $\mathrm{Zn}$ in soils was significantly and negatively correlated with vegetable $\mathrm{Zn}(\mathrm{r}=-0.704)$ and $\mathrm{Fe}(\mathrm{r}=-0.587)$ concentrations but positively correlated with $\mathrm{Mn}(\mathrm{r}=0.543)$ concentration in vegetables grown in Ihumwa soils (Table 10). Soil Fe (range 3.29 to $12.48 \mathrm{mg} / \mathrm{kg}$ ) and vegetable Fe concentration 
Table 10. Descriptive statistics and correlation analysis of concentrations of selected nutrients in vegetables and soil properties in Ihumwa, Dodoma Municipality.

\begin{tabular}{|c|c|c|c|c|c|}
\hline Vegetables nutrient concer & & & & & \\
\hline Parameter & $\mathrm{N}$ & Mean & $\mathrm{SD}$ & Min & Max \\
\hline $\mathrm{K}(\%)$ & 29 & 2.07 & 0.88 & 0.55 & 4.23 \\
\hline $\mathrm{Zn}(\mathrm{mg} / \mathrm{kg})$ & 29 & 96.02 & 30.05 & 29.11 & 144.13 \\
\hline $\mathrm{Fe}(\mathrm{mg} / \mathrm{kg})$ & 29 & 1037.00 & 517.22 & 0.56 & 1881.00 \\
\hline $\mathrm{Cu}(\mathrm{mg} / \mathrm{kg})$ & 29 & 30.11 & 36.40 & 8.83 & 175.54 \\
\hline $\mathrm{Mn}(\mathrm{mg} / \mathrm{kg})$ & 29 & 195.42 & 134.17 & 100.00 & 748.53 \\
\hline \multicolumn{6}{|l|}{ Soil properties } \\
\hline $\mathrm{pH}\left(\mathrm{H}_{2} \mathrm{O}\right)$ & 29 & 7.58 & 0.71 & 5.70 & 8.80 \\
\hline $\mathrm{EC}(\mathrm{dS} / \mathrm{m})$ & 29 & 0.23 & 0.16 & 0.07 & 0.90 \\
\hline $\mathrm{CEC}(\mathrm{cmolc} / \mathrm{kg})$ & 29 & 14.59 & 2.59 & 9.60 & 20.00 \\
\hline $\mathrm{P}(\mathrm{mg} / \mathrm{kg})$ & 29 & 12.02 & 9.06 & 2.31 & 31.95 \\
\hline $\mathrm{Zn}(\mathrm{mg} / \mathrm{kg})$ & 29 & 1.80 & 0.85 & 0.36 & 3.43 \\
\hline $\mathrm{Fe}(\mathrm{mg} / \mathrm{kg})$ & 29 & 6.61 & 2.14 & 3.29 & 12.48 \\
\hline $\mathrm{Cu}(\mathrm{mg} / \mathrm{kg})$ & 29 & 0.99 & 0.25 & 0.61 & 1.48 \\
\hline $\mathrm{Mn}(\mathrm{mg} / \mathrm{kg})$ & 29 & 8.08 & 3.60 & 1.59 & 15.04 \\
\hline \multicolumn{6}{|c|}{ Pearson correlation coefficients $(r)$} \\
\hline & & Soil Zn & Soil Fe & Soil CEC & Soil pH \\
\hline Vegetable $\mathrm{Zn}$ & 29 & $-0.704^{\star}$ & -0.093 & $-0.411^{*}$ & -0.018 \\
\hline Vegetable Fe & 29 & $-0.587^{\star}$ & $-0.587^{\star}$ & $-0.600^{*}$ & -0.277 \\
\hline Vegetable Mn & 29 & $0.543^{*}$ & 0.213 & 0.195 & -0.239 \\
\hline
\end{tabular}

$\mathrm{n}=$ number of observation; SD-standard deviation; Min = minimum; Max = maximum; ${ }^{*}$ Significant at alpha $=0.05$.

were significantly negatively correlated $(\mathrm{r}=-0.587)$. Soil CEC $(9.6$ to 20 cmolc $/ \mathrm{kg}$ ) was significantly and negatively correlated with vegetable $\mathrm{Zn}(\mathrm{r}=$ $-0.411)$ and vegetable $\mathrm{Fe}(\mathrm{r}=-0.600)$ (Table 10). No significant correlation was observed between soil $\mathrm{pH}$ and nutrient concentrations in vegetables in Ihumwa soils.

The results show that for Ihumwa, micronutrient concentrations in vegetables were influenced by soil $\mathrm{Zn}$, soil Fe and CEC. The negative correlation of vegetable $\mathrm{Zn}$ and soil $\mathrm{Zn}$ concentration was unexpected, but further alludes to complex phenomena and possibly nonlinear relationship between soil constituents and micronutrient availability in soils [60], especially in high $\mathrm{pH}$ semi-arid soils like those of Dodoma. The $\mathrm{Zn}$ concentration in soils of Ihumwa was variable, ranging from deficient $(0.35 \mathrm{mg} / \mathrm{kg})$ to sufficient $(3.45 \mathrm{mg} / \mathrm{kg})$, while $\mathrm{Zn}$ levels in vegetables were also in the sufficiency range of 29.11 to $144.13 \mathrm{mg} / \mathrm{kg}$ (Table 5). The negative correlation between vegetable Fe concentration and soil $\mathrm{Zn}$ can be attributed to antagonism and competition between $\mathrm{Fe}$ and $\mathrm{Zn}$ cations for plant absorption, where in this case it appears that high levels of soil $\mathrm{Zn}$ in these soils 
tend to reduce absorption of Fe. Like in the vegetable $\mathrm{Zn}$ and soil $\mathrm{Zn}$ correlation, the negative correlation between vegetable $\mathrm{Fe}$ and soil $\mathrm{Fe}$ was unexpected, which suggests some complex association since the soil Fe concentration was not in the toxic range. However, the soil and vegetable Fe concentrations are in the sufficiency range and do not raise any management concerns. Therefore, in Ihumwa, soil $\mathrm{Zn}$, soil Fe and CEC in combination or individually determined the concentration of $\mathrm{Zn}, \mathrm{Fe}$ and $\mathrm{Mn}$ concentrations in the vegetables.

\section{Conclusion}

The chemical properties and plant nutrient concentrations in the soils studied are diverse, with medium soil $\mathrm{pH}$ in humid alluvial soils of Kilombero to high soil pH in the semi-arid soils of Dodoma. Soil P was deficient in some vegetable growing soils of Dodoma, but sufficient in Kilomero soils. Among the micronutrients, $\mathrm{Zn}$ and Fe were sufficient in most of the soils but were deficient in one vegetable growing soil of Dodoma, while $\mathrm{Cu}$ was deficient in Kilombero soils. All vegetables from all sites had mineral micronutrient ( $\mathrm{Zn}, \mathrm{Cu}, \mathrm{Fe}$ and $\mathrm{Mn}$ ) concentrations at sufficient levels and within MAC for human health for most sites, except the vegetables from Kilombero that had low $\mathrm{Cu}$, and vegetables from two sites in Hombolo that had low Zn. Soil fertility management affected concentrations of macronutrients $(\mathrm{N}, \mathrm{P}, \mathrm{K}, \mathrm{Ca}$ and $\mathrm{Mg}$ ) but not micronutrients in the vegetables. However, SFMP affected $\mathrm{Zn}, \mathrm{Cu}, \mathrm{Fe}$ and $\mathrm{Mn}$, and the effect differed among soils. The relationships between soil chemical properties and vegetable mineral concentrations were direct; some were complex and some differed among sites due to differences in soil properties across SFMP. Soil fertility management for vegetables influenced vegetable mineral quality for human health, and differed among soils and agro-climatic zones.

\section{Acknowledgements}

This work was supported by the Innovative Agricultural Research Initiative (iAGRI), a Feed the Future Project of USAID. The field and laboratory assistance from Geoffrey Malimwengu, Farid Magoma and Mr. Waziri are highly appreciated. The technical assistance in laboratory analysis by Mr. Mohamed Hamis and Mr. Salum Marangi is gratefully acknowledged.

\section{References}

[1] Singh, J. (2016) Biofortification of Food Legumes and Bioavailability of Nutrients. In: Singh, U., Praharaj, C.S., Singh, S.S. and Singh, N.P., Eds., Biofortification of Food Crops, Springer, New Delhi, 51-60. https://doi.org/10.1007/978-81-322-2716-8_5

[2] WHO/FAO (World Health Organization and Food/Agriculture Organization) Experts (2004) Vitamin and Mineral Requirements in Human Nutrition. 2nd Edition. http://www.who.int/nutrition/publications/micronutrients/9241546123/en/

[3] Muthayya, S., Rah, J.H., Sugimoto, J.D., Roos, F.F., Kraemer, K. and Black, R.E. (2013) The Global Hidden Hunger Indices and Maps: An Advocacy Tool for Action. PLoS ONE, 8, e67860. https://doi.org/10.1371/journal.pone.0067860 
[4] NBS (National Bureau of Statistics, Tanzania and ICF Macro) (2011) Micronutrients: Results of the 2010 Tanzania Demographic and Health Survey. NBS and ICF Macro, Dar Es Salaam, Tanzania.

[5] WHO (World Health Organization of United Nations) (2016) Evaluating the Public Health Significance of Micronutrient Malnutrition. Part II. http://www.who.int/nutrition/publications/micronutrients/GFF_Part_2_en.pdf

[6] Allen, L., de Bonoist, B., Dary, O. and Hurrel, R., Eds. (2009) Evaluating the Public Health Significance of Micronutrient Malnutrition (Part II). In: Guidelines on Food Fortification with Micronutrients, World Health Organization of the United Nations (WHO) and Food and Agricultural Organization of the United Nations (FAO), 41-92.

[7] Global Report (2009) Investing in the Future: A United Call to Action on Vitamin and Mineral Deficiencies.

http://www.unitedcalltoaction.org/documents/Investing_in_the_future.pdf

[8] The World Bank. Undated. Tanzania Nutrition at a Glance. http://siteresources.worldbank.org/NUTRITION/Resources/281846-1271963823772 /Tanzania.pdf

[9] Bouis, H., Boy-Gallego, E. and Meenakshi, J.V. (2012) Micronutrient Malnutrition: Causes, Prevalence, Consequences, and Interventions. In: Bruulsema, T.W., Heffer, P., Welch, R.M., Cakmak, I. and Moran, K., Eds., Fertilizing Crops to Improve Human Health: A Scientific Review. Volume I, Food and Nutrition Committee, International Plant Nutrition Institute, Norcross, GA, USA, International Fertilizer Industry Association, Paris, France, 29-64.

[10] Briefel, R.R., Bialostosky, K., Kennedy-Stephenson J., McDowell, M.A., Ervin, R.B.R. and Wright, J.D. (2000) Zinc Intake of the U.S. Population: Findings from the Third National Health and Nutrition Examination Survey, 1988-1994. Journal of Nutrition, 130, 1367S-1373S.

[11] de Valenca, A.W. and Bake, A. (2016) Micronutrient Management for Improving Harvests, Human Nutrition, and the Environment. Background Document for Stakeholder Workshop on Micronutrients, Wageningen University, Food and Business Knowledge Platform, IFDC, 21p.

[12] TFNC (Tanzania Food and Nutrition Centre) (2006) Strategic Plan 2005/20062009/2010. TFNC Report No. 2006, Dar es Salaam, Tanzania.

[13] Jimenez, M. and Stone-Jimenez, M. (2014) Preventing Moderate Acute Malnutrition (MAM) through Nutrition Specific Interventions. CMAM Forum Technical Brief. EC (European Commission)-UNICEF (United Nations Children's Fund), 39 p.

[14] O’Dell, B.L. and Sunde R.A. (1997) Handbook of Nutritionally Essential Mineral Elements. Marcel Dekker Inc., New York, 1-12.

[15] Joy, E.J.M., Stein, A.J., Young, S.D., Ander, E.L., Watts, M.J. and Broadley, M.R. (2015) Zinc-Enriched Fertilisers as a Potential Public Health Intervention in Africa. Plant and Soil, 389, 1-24. https://doi.org/10.1007/s11104-015-2430-8

[16] Othman, O.C. (2001) Heavy Metals in Green Vegetables and Soils from Vegetable Gardens in Dar Es Salaam, Tanzania. Tanzania Journal of Science, 27, 37-48. https://doi.org/10.4314/tjs.v27i1.18334

[17] Ahmad, J.U. and Goni, M.A. (2010) Heavy Metal Contamination in Water, Soil, and Vegetables of the Industrial Areas in Dhaka, Bangladesh. Environmental Monitoring and Assessment, 166, 347-357. https://doi.org/10.1007/s10661-009-1006-6

[18] Ferri, R., Hashim, D., Smith, D.R., Guazzetti, S., Donna, F., Ferretti, E., Curatolo, M., Moneta, C., Maria Beone, G. and Lucchini, R.G. (2015) Metal Contamination of Home Gardens Soils and Cultivated Vegetables in the Province of Brescia, Italy: Implications for Human Exposure. Science of Total Environment, 518-519, 507517. 
[19] Kalala, A.M. (2017) Optimizing Macronutrients and Zinc Levels for Rice Production in Kilombero District: Implications for Appropriate Fertilizer Recommendations. PhD Dissertation, Sokoine University of Agriculture, Morogoro, Tanzania.

[20] Dodoma Regional Commissioner Office (2017) Dodoma Region. United Republic of Tanzania. http://www.dodoma.go.tz/index.php/pages/details/7

[21] NSS (National Soil Services) (1983) Soil Survey Report of Dodoma Capital City District. Vol. A. Main Report. AG: URT/73/006. Soil Survey Report No. 4, Food and Agriculture Organization of the United Nations, Tanga, Tanzania, $127 \mathrm{p}$.

[22] Mwasyika, T. (2015) Influence of Soil Fertility on Mineral Nutritive Quality of Cereals and Vegetables Grown on Typical Soils of Dodoma Capital District, Tanzania. MSc Dissertation, Sokoine University of Agriculture, Morogoro, Tanzania.

[23] McLean, E.O. (1986) Soil pH and Lime Requirement. In: Page, A.L., Miller, R.H. and Keeny, D.R., Eds., Methods of Soil Analysis, Part 2, Chemical and Mineralogical Properties, 2nd Edition, Agronomy Monograph No. 9, Amer. Soc. Agron. and Soil Sci. Soc. Amer., Madison, Wisconsin, 199-223.

[24] Nelson, D.W. and Sommers, L.E. (1982) Total Carbon, Organic Carbon and Organic. In: Page, A.L., Miller, R.H. and Keeny, D.R., Eds., Methods of Soil Analysis, Part 2, Chemical and Microbiological Properties, Amer. Soc. Agron, Madison, 539579.

[25] Bremner, J.M. and Mulvaney, C.S. (1982) Total Nitrogen. In: Page, L.A., Milley, R.H. and Keeney, D.R., Eds., Method of Soil Analysis, Part 2, 2nd Edition, Agronomy Monograph No. 9, Amer. Soc. Agron. Inc., Madison, Wisconsin, 595-622.

[26] Bray, R.H. and Kurtz, L.T. (1945) Determination of Total Nitrogen and Available Forms of Phosphorus in Soils. Soil Science, 58, 39-46. https://doi.org/10.1097/00010694-194501000-00006

[27] Olsen, S.R., Cole, C.V., Watanabe, F.S. and Dean, L.A. (1954) Estimation of Available Phosphorus in Soils by Extraction with Sodium Bicarbonate. U.S. Department of Agriculture Circular No. 939.

[28] Murphy, J. and Riley, J.P. (1962) A Modified Single Solution Method for the Determination of Phosphate in Natural Waters. Analytica Chimica Acta, 27, 31-36.

[29] Lindsay, W.L. and Norvel, W.A. (1978) Development of a DTPA Soil Test for Zinc, Iron, Manganese and Copper. Soil Science Society of America Journal, 42, 421-428. https://doi.org/10.2136/sssaj1978.03615995004200030009x

[30] Moberg, J.P. (2001) Soil Analysis Manual. Revised Edition.

[31] SAS Institute Inc. (2002) SAS Statistical Analysis Software for Windows 9.00. Cary, NC, USA.

[32] Landon, J.L. (1991) Booker Tropical Soil Manual. A Handbook for Soil Survey and Agricultural Land Evaluation in the Tropics and Subtropics. Longman Group FE limited, New York, 113-138.

[33] Islam, A.K.M.S., Edwards, D.G. and Asher, C.J. (1980) pH Optima for Crop Growth: Results of a Flowing Solution Culture Experiment with Six Species. Plant and Soil, 54, 339-357. https://doi.org/10.1007/BF02181830

[34] Jones, C., Brown, B.D., Engel, R., Horneck, D. and Olson-Kurtz, K. (2013) Factors Affecting Nitrogen Fertilizers Volatilization. Montana State University Extension, United States Department of Agriculture, Bozeman, MT, EB0208, 1-5.

[35] Chalk, P.M., Craswell, E.T., Polidoro, J.C. and Chen, D. (2015) Fate and Efficiency of $15 \mathrm{~N}$-Labelled Slow- and Controlled-Release Fertilizers. Nutrient Cycling in Agroecosystems, 102, 167-178. https://doi.org/10.1007/s10705-015-9697-2

[36] Kitemangu, Z. (2014) Gender Dimensions of Soil Fertility Management Practices in Vegetable Production in Dodoma Municipality and Kilombero District, Tanzania. MA Dissertation, Sokoine University of Agriculture, Morogoro, Tanzania.

[37] Maerere, A.P., Kimbi, G.G. and Nonga, D.L.M. (2001) Comparative Effectiveness of Animal Manures on Soil Chemical Properties, Yield and Root Growth of Amaran- 
thus (Amaranthus cruentus L.). African Journal of Science and Technology, 1, 1421.

[38] Long, X.X., Yang, X.E., Ni, W.Z., Ye, Z.Q., He, Z.L., Calvert, D.V. and Stoffella, J.P. (2003) Assessing Zinc Thresholds for Phytotoxicity and Potential Dietary Toxicity in Selected Vegetable Crops. Communications in Soil Science and Plant Analysis, 34, 1421-1434. https://doi.org/10.1081/CSS-120020454

[39] Yang, X., Long, X., Ni, W., Ye, Z., He, Z., Stoffella, P.J. and Calvert, D.V. (2002) Assessing Copper Thresholds for Phytotoxicity and Potential Dietary Toxicity in Selected Vegetable Crops. Journal of Environmental Science and Health, Part B-Pesticides, Food Contaminants, and Agricultural Wastes, 37, 625-635. https://doi.org/10.1081/PFC-120015443

[40] Walker, D.J., Clemente, R. and Bernal, M.P. (2004) Contrasting Effects of Manure and Compost on Soil pH, Heavy Metal Availability and Growth of Chenopodium album L. in a Soil Contaminated by Pyritic Mine Waste. Chemosphere, 57, 215-224.

[41] White, J.G. and Zasoski, R.J. (1999) Mapping Soil Micronutrients. Field Crops Research, 60, 11-26.

[42] Tandon, H.L.S. (1995) Micronutrients in Soils, Crops and Fertilizer: A Source BookCum-Directory. Fertilizer Development and Consultation Organic. New Delhi, India, $164 \mathrm{p}$.

[43] Massawe, B.H.J. and Amuri, N. (2012) Soil Fertility and Agronomic Practices Evaluation for Improved Rice Production in Lowland Rice Producing Areas Kilombero and Wami Valleys. A Report for ACDI/VOCA Project, Morogoro, Tanzania, $255 \mathrm{p}$.

[44] Gharibu, F.N. (2014) Effectiveness of Minjingu Mazao as a Source of Phosphorus, Zinc and Copper in Rice Production In Kilombero District-Morogoro, Tanzania. MSc Dissertation, Sokoine University of Agriculture Morogoro, Tanzania, 87 p.

[45] Kumar, A., Choudhary, A.K., Pooniya, V., Suri, V.K. and Singh, U. (2016) Soil Factors Associated with Micronutrient Acquisition Perspective. In: Singh, U., Praharaj, C.S., Singh, S.S. and Singh, N.P., Eds., Biofortification of Food Crops, Springer, New Delhi, 159-176. https://doi.org/10.1007/978-81-322-2716-8_13

[46] Bosiacki, M. and Tyksinski, W. (2009) Copper, Zinc, Iron and Manganese Content in Edible Parts of Some Fresh Vegetables Sold on Markets in Poznan. Journal of Elementology, 14, 13-22. https://doi.org/10.5601/jelem.2009.14.1.02

[47] FAO/WHO (2011) Codex Alimentarius Commission. Joint FAO/WHO Food Standards Programme Codex Committee on Contaminants in Foods. Fifth Session. 2125 March 2011. Working Document for Information and Use in Discussions Related to Contaminants and Toxins in the GSCTFF (Prepared by Japan and the Netherlands) CF/5 INF/1. The Hague, The Netherlands, 89 .

[48] Campbell, C.R., Ed. (2000) Reference Sufficiency Ranges for Plant Analysis in the Southern Region of the United States. Southern Cooperative Series Bulletin No. 394.

[49] Bost, M., Houdart, S., Oberli, M., Kalonji, E., François, J.H. and Margaritis, I. (2016) Dietary Copper and Human Health: Current Evidence and Unresolved Issues. Journal of Trace Elements in Medicine and Biology, 35, 107-115.

[50] FAO/WHO (Food and Agriculture Organization of the United Nations/World Health Organization) (2002) Codex Alimentarius General Standards for Contaminants and Toxins in Food. Schedule 1 Maximum and Guideline Levels for Contaminants and Toxins in Food. Reference CX/FAC 02/16. Joint FAO/WHO Food Standards Programme, Codex Committee, Rotterdam, The Netherlands, $341 \mathrm{p}$.

[51] Shaheen, S.M., Rinklebeb, J. and Tsadilas, C.D. (2015) Fractionation and Mobilization of Toxic Elements in Floodplain Soils from Egypt, Germany, and Greece: A Comparison Study. Eurasian Soil Science, 48, 1317-1328. https://doi.org/10.1134/S1064229315120121

[52] Chove, B.E., Ballegu, W.R. and Chove, L.M. (2006) Copper and Lead Levels in Two 
Popular Leafy Vegetables Grown around Morogoro Municipality, Tanzania. Tanzania Health Research Bulleti, 8, 37-40. https://doi.org/10.4314/thrb.v8i1.14269

[53] Kumar, V., Sinha, A.K., Makkar, H.P.S. and Becker, K. (2010) Dietary Roles of Phytate and Phytase in Human Nutrition: A Review. Food Chemistry, 120, 945-959.

[54] Horiguchi, T. (1988). Mechanism of Manganese Toxicity and Tolerance of Plants: IV. Effects of Silicon on Alleviation of Manganese Toxicity of Rice Plants. Soil Science and Plant Nutrition, 34, 65-73. https://doi.org/10.1080/00380768.1988.10415580

[55] Finley, J.W. (1999) Manganese Absorption and Retention by Young Women Is Associated with Serum Ferritin Concentration. American Journal of Clinical Nutrition, 70, 37-43.

[56] Antoniadis, V., Shaheen, S.M., Boersch, J., Frohne, T., Laing, G.D. and Rinklebe, J. (2017) Bioavailability and Risk Assessment of Potentially Toxic Elements in Garden Edible Vegetables and Soils around a Highly Contaminated Former Mining Area in German. Journal of Environmental Management, 186, 192-200.

[57] Rahman, M.M., Asaduzzaman, M. and Naidu, R. (2013) Consumption of As and Other Elements from Vegetables and Drinking Water from an As-Contaminated Area of Bangladesh. Journal of Hazardous Materials, 262, 1056-1063.

[58] Santos, D., Batoreu, C., Mateus, L., dos Santos, AP.M. and Aschner, M. (2014) Manganese in Human Parenteral Nutrition: Considerations for Toxicity and Biomonitoring. Neurotoxicology, 43, 36-45.

[59] Kalala, M.A, Amuri, N.A. and Semoka, J.M.R. (2016) Response of Rice to Phosphorus and Potassium Fertilization Based on Nutrient Critical Levels in Plants and Soils of Kilombero Valley. Advances in Research, 7, 1-12. https://doi.org/10.9734/AIR/2016/26368

[60] Udeigwe, T.K., Eichmann, M., Eze, P.N., Ogendi, G.M., Morris, M.N. and Riley, M.R. (2016) Copper Micronutrient Fixation Kinetics and Interactions with Soil Constituents in Semi-Arid Alkaline Soils. Soil Science and Plant Nutrition, 62, 289296. https://doi.org/10.1080/00380768.2016.1197046

[61] Kumar, I.A. and Babel, A. (2013) Extractable Micronutrients Status in Relation to Other Soil Properties in Jangargari, Yamaltu-Deba Local Government Area, Gombe State. Asian Journal of Agriculture and Food Science, 1, 217-221.

[62] Marschner, H. (2002) Mineral Nutrition of Higher Plants. 2nd Edition, Academic Press. San Diego, CA, 889 p.

[63] Suri, V.K., Choudhary, A.K., Chander, G., Gupta, M.K. and Dutt, N. (2011) Improving Phosphorus Use through Co-Inoculation of Vesicular Arbuscular Mycorrhizal Fungi and Phosphate Solubilizing Bacteria in Maize in an Alfisol. Communications in Soil Science and Plant Analysis, 42, 2265-2273. https://doi.org/10.1080/00103624.2011.602451

[64] Fink, J.R., Inda, A.V., Tiecher, T. and Barron, V. (2016) Iron Oxides and Organic Matter on Soil Phosphorus Availability. Ciencia e Agrotecnologia, 40, 369-379. https://doi.org/10.1590/1413-70542016404023016 
Submit or recommend next manuscript to SCIRP and we will provide best service for you:

Accepting pre-submission inquiries through Email, Facebook, LinkedIn, Twitter, etc. A wide selection of journals (inclusive of 9 subjects, more than 200 journals)

Providing 24-hour high-quality service

User-friendly online submission system

Fair and swift peer-review system

Efficient typesetting and proofreading procedure

Display of the result of downloads and visits, as well as the number of cited articles Maximum dissemination of your research work

Submit your manuscript at: http://papersubmission.scirp.org/

Or contact jacen@scirp.org 